Florida International University FIU Digital Commons

4-28-2013

\title{
Root:Shoot Ratio and Specific Leaf Area Along an Elevational Gradient in the Peruvian Andes
}

Catherine Heidy Bravo Avila

Florida International University, cbrav006@fiu.edu

DOI: $10.25148 /$ etd.FI13042333

Follow this and additional works at: https://digitalcommons.fiu.edu/etd

Part of the Ecology and Evolutionary Biology Commons

\section{Recommended Citation}

Bravo Avila, Catherine Heidy, "Root:Shoot Ratio and Specific Leaf Area Along an Elevational Gradient in the Peruvian Andes" (2013). FIU Electronic Theses and Dissertations. 884.

https://digitalcommons.fiu.edu/etd/884 


\title{
FLORIDA INTERNATIONAL UNIVERSITY
}

Miami, Florida

\section{ANALYZING ROOT:SHOOT RATIO AND SPECIFIC LEAF AREA ALONG AN} ELEVATIONAL GRADIENT IN THE PERUVIAN ANDES

\author{
A thesis submitted in partial fulfillment of \\ the requirements for the degree of \\ MASTER OF SCIENCE \\ in \\ BIOLOGY
}

by

Catherine H. Bravo Avila 
To: Dean Kenneth G. Furton

College of Arts and Sciences

This thesis, written by Catherine H. Bravo Avila, and entitled Analyzing root:shoot ratio and specific leaf area along an elevational gradient in the Peruvian Andes, having been approved in respect to style and intellectual content, is referred to you for judgment.

We have read this thesis and recommend that it be approved.

Jennifer H. Richards

Steven F. Oberbauer

Kenneth J. Feeley, Major Professor

Date of Defense: March 28, 2013

The thesis of Catherine H. Bravo Avila is approved.

\begin{tabular}{r} 
Dean Kenneth G. Furton \\
College of Arts and Sciences \\
\hline Dean Lakshmi N. Reddi \\
University Graduate School
\end{tabular}

Florida International University, 2013 
(C) Copyright 2013 by Catherine H. Bravo Avila

All rights reserved. 


\section{ACKNOWLEDGMENTS}

I could not have completed this thesis without the support of many. First, I want to thank my family for their love and invaluable support. I also want to specially thank my advisor, Dr. Kenneth J. Feeley, for his continuous support through my research and academic experience in FIU.

I thank my committee, Dr. Jennifer Richards and Dr. Steve Oberbauer, for their guidance and support through the development of my thesis. Also, a very special thank you to the members of my lab: Evan Rehm, Brian Machovina, Paulo Olivas, and James Stroud, for their friendship and help to improve this document. I thank my Peruvian colleagues from the ABERG house in Cusco for their companionship and help with logistics. Also, I want to thank Nicole Cortez and Laura Espinola, undergraduate students at FIU that provided help in the lab.

Thanks for the generous support to Sigma Xi for a Grant-in-Aid of Research, the FIU Latin American and Caribbean Center for a Tinker Field Grant, the Kelly Foundation for a Tropical Botany Small Grant. Also, I want to thank the Fulbright Fellowship Program for financial support in my master's studies, Dr. Krish Jayachandran (Dr. Jay) for his help with the soil permit needed for this research, and the Manu National Park personnel in Cusco and SERNANP Peru for granting the research permit.

Finally, I dedicate this thesis to my friend and partner in the field Flor Zamora (1982-2012). 
ABSTRACT OF THE THESIS

ANALYZING ROOT:SHOOT RATIO AND SPECIFIC LEAF AREA ALONG AN ELEVATIONAL GRADIENT IN THE PERUVIAN ANDES

by

Catherine H. Bravo Avila

Florida International University, 2013

Miami, Florida

\section{Professor Kenneth J. Feeley, Major Professor}

Andean montane forests are one of the most diverse ecosystems on Earth, but are also highly vulnerable to climate change. Therefore, the link between plant distribution and ecosystem productivity is a critical point to investigate in these ecosystems. Are the patterns in productivity observed in montane forest due to species turnover along the elevational gradients? Methodological constraints keep this question unanswered. Also, despite their importance, belowground biomass remains poorly quantified and understood. I measured two plant functional traits in seedlings, root:shoot ratio and specific leaf area, to identify different strategies in growth and biomass allocation across elevations. A tradeoff in specific leaf area with elevation was found in only one species, and no generalized directional change was detected with elevations for root:shoot ratio. Lack of information for the ontogeny of the measured plant traits could confounding the analysis. 


\section{TABLE OF CONTENTS}

CHAPTER $\quad$ PAGE

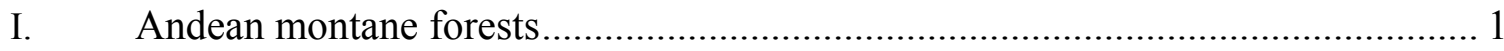

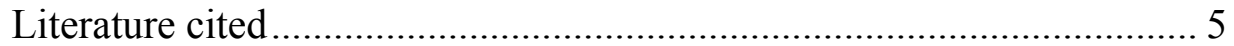

II. Analyzing root:shoot ratio and specific leaf area in a cloudforest along an elevational gradient in the Peruvian Andes .................................................... 13

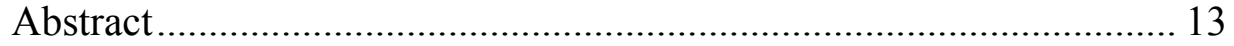

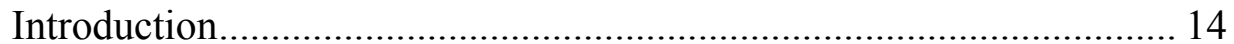

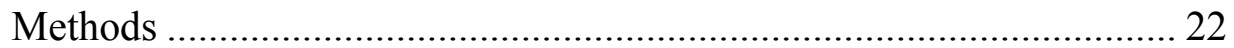

Study site ........................................................................ 22

Seedling species collected ................................................... 24

Canopy pictures and soil samples ........................................... 25

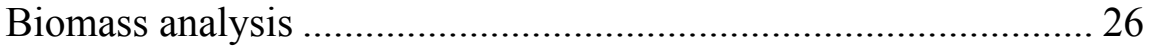

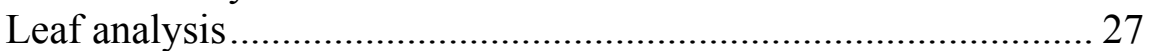

Statistical Analysis ............................................................ 28

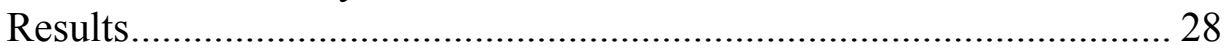

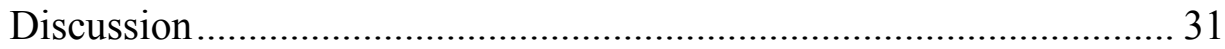

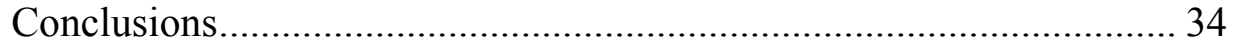

Literatured cited ........................................................................ 35 


\section{LIST OF FIGURES}

FIGURE

PAGE

Figure 1. View of the field study from $3500 \mathrm{~m}$ asl, top of the ridge called Trocha Union, to the east over the study site in the Kosnipata Valley, Cusco - Peru. Seedlings were collected along the shown ridge from $3450 \mathrm{~m}$ to $2700 \mathrm{~m}$............................................... 45

Figure 2. Seedlings of the six focal species taken in the field................................... 46

Figure 3. Histograms that show the number of seedlings collected by species per elevation.

Figure 4. Mean basal diameter ( $\mathrm{mm}$ ) presented by species across the elevational gradient. 48

Figure 5. Mean shoot height $(\mathrm{cm})$ presented by species across the elevational gradient. 49

Figure 6. Regression line between plant height $(\mathrm{cm})$ and basal diameter $(\mathrm{mm})$, including the $90 \%$ confidence interval (gray color), presented by species. Pearson correlation coefficients (r) are reported.

Figure 7. Regression line between root:shoot ratio and height $(\mathrm{cm})$, including the $90 \%$ confidence interval (gray color), presented by species.

Figure 8. Regression line between root:shoot ratio and basal diameter ( $\mathrm{mm})$, including the $90 \%$ confidence interval (gray color), presented by species. 52

Figure 9. Regression line between specific leaf area $\left(\mathrm{mm}^{2} / \mathrm{mg}\right)$ and height $(\mathrm{cm})$, including the $90 \%$ confidence interval (gray color), presented by species. 53

Figure 10. Regression line between specific leaf area $\left(\mathrm{mm}^{2} / \mathrm{mg}\right)$ and diameter $(\mathrm{mm})$, including the $90 \%$ confidence interval (gray color), presented by species. 54

Figure 11. Regression line between root:shoot ratio residuals and elevation ( $\mathrm{m}$ asl), including the $90 \%$ confidence interval (gray color), presented by species.

Figure 12. Regression line between specific leaf area residuals and elevation ( $\mathrm{m}$ asl), including the $90 \%$ confidence interval (gray color), presented by species. 56

Figure 13. Canopy openness (\%) taken from each location where seedlings were collected ( $\mathrm{n}=190$ pictures).... 
Figure 14. Regression line between root:shoot ratio residuals and canopy openness (\%), including the $90 \%$ confidence interval (gray color), presented by species........................58

Figure 15. Regression line between specific leaf area residuals and canopy openness (\%), including the $90 \%$ confidence interval (gray color), presented by species. 59

Figure 16. Regression line that shows the distribution of soil $\mathrm{pH}$ along the elevational gradient.(n=119) 60

Figure 17. Regression line between root:shoot ratio residuals and $\mathrm{pH}$, including the $90 \%$ confidence interval (gray color), presented by species......................................................... 61

Figure 18. Regression line between specific leaf area residuals and $\mathrm{pH}$, including the $90 \%$ confidence interval (gray color), presented by species. 62 


\section{CHAPTER 1: ANDEAN MONTANE FORESTS}

The Tropical Andes extend over $4000 \mathrm{~km}$ from $11^{\circ} \mathrm{N}$ to $23^{\circ} \mathrm{S}$ and include territories from the Venezuelan western slopes to the Bolivian, Chilean and Argentinian frontiers. Elevations range from 600-800 $\mathrm{m}$ to approximately $6000 \mathrm{~m}$ above sea level. Within the central Andes, the eastern slopes located between high elevation grasslands (puna or páramo) and the lowland Amazon forest are covered in tropical montane cloudforests. As a result of their steepness, elevation can change 3000-4000 m across a horizontal distance of less $20 \mathrm{~km}$. This dramatic altitudinal gradient over a relatively small area holds many species with narrow elevational ranges that allows the Andes to support high levels of plant and animal diversity, including many endemic species (Myers et al. 2000). Indeed, the tropical Andes were considered by Myers et al. (2000) to be one of the 25 global biodiversity hotspots of conservation concern, due to their high concentration of species coupled with the ongoing threat of habitat loss. More specifically, the tropical Andes support $6.7 \%$ and $5.7 \%$ of the world's endemic plant and vertebrate animal species, respectively, and it has been estimated that only $25 \%$ of primary vegetation remains (Myers et al. 2000). Deforestation, habitat fragmentation, and human land use are believed to have already caused extensive biodiversity loss; currently, climate change makes the Andean montane forests even more vulnerable to biodiversity loss (Bush 2002, Feeley \& Silman 2010b).

In addition to their high biodiversity value, Andean montane forests are important for the provisioning of ecosystem services relating to water capture (Buytaert et al. 2009), regional climatic regulation (Larsen 2012), pollination of nearby crops, and 
carbon storage (Gibbon et al. 2010). The majority of studies assessing carbon pools and sequestration in the tropics have been conducted in lowland forests (Clark et al. 2003; Feeley et al. 2007), while the ecosystem properties of the tropical Andes remain relatively unknown (Moser et al. 2011), hindering the development of realistic global and regional carbon budgets, as well as of predictions for the effects of climate change.

Two principal approaches employed to investigate forest responses to altered climate conditions are field manipulations and observational studies (Gradstein et al. 2008). Field manipulations are controlled experiments where one or more climatic variable is manipulated and the biological responses are measured. For example, $\mathrm{CO}_{2}$ enrichment experiments (e.g., FACE, Ainsworth \& Long 2005) and warming experiments (Rustad et al. 2001) have greatly increased our understanding of the physiological responses of temperate forests to climate change. However, no large-scale warming or $\mathrm{CO}_{2}$ addition experiments have been conducted in the tropics to date (Aronson \& McNulty 2009, Feeley et al. 2012), although a large-scale drought simulation experiment has been completed in the lowland rainforest of Brazil (Da Costa et al. 2010). This study showed that after a seven year experimental drought, aboveground wood production decreased by an average of $32 \%$ in a 1 ha plot of eastern Amazonian forest, mainly due to reduced stem density and decreased average growth rates of large trees (DBH $>40 \mathrm{~cm}$ ). While field manipulations can provide important insights, they are logistically and financially challenging, which can reduce statistical power and constrain site selection. These factors have prevented their application in tropical Andean montane forests. 
Another approach that may provide insights into how species respond to changes in variable climatic conditions is the use of elevational gradients as climate proxies. Since climate changes with elevation, elevational gradients are considered "natural laboratories" to test both long-term and transient effects of climate on species and ecosystems (Malhi et al. 2010). For example, temperature changes linearly with elevation according to the adiabatic lapse rate (Raich et al. 1997, Kitayama \& Aiba 2002, Rapp 2010, Girardin et al. 2010), and thus elevational gradients can also be considered temperature gradients. Unlike latitudinal gradients, studies on tropical elevational gradients can avoid both the confounding effects of seasonality on temperatures due to changes in sun angle and day length, and differences of biogeographic history among sites (Malhi et al. 2010), although local variation in microclimate variables, such as cloudiness and moisture, have been reported for some elevational gradients, and these could possibly affect plant performance and biomass allocation patterns (Rapp 2010). Studies in tropical montane forests in Borneo, Puerto Rico, Hawaii, Venezuela, Ecuador and Peru have used vegetation plots along altitudinal gradients to evaluate the changes of aboveground biomass and productivity with elevation (Delaney et al. 1997, Raich et al. 1997, Waide et al. 1998, Aiba \& Kitayama 1999, Girardin et al. 2010, Moser et al. 2011). These studies found that tree architecture changed from slender to robust trunks at higher altitudes. Some studies have reported that mean leaf area decreases with elevation, possibly as an adaptation/acclimation to cope with limited water supply and nutrient availability, as $\mathrm{N}$ availability generally decreases with elevation regardless of geological substrates (Raich et al. 1997, Vitousek \& Howarth 2008, van de Weg et al. 2009). Moreover, the decrease of aboveground net primary productivity with elevation has been 
consistently reported as a key characteristic of tropical montane cloudforests (Aiba \& Kitayama 1999, Leuschner et al. 2007, Girardin et al. 2010)

One important aspect that limits insight into the function of tropical montane cloudforests is the scarce climatic data available along elevational gradient. In a study along an elevational gradient in the southeastern Andes of Peru, Rapp (2010) used an array of micro-meteorological stations within a cloud forest in Peru, complemented with climate data from the lowlands and highlands, to produce the most comprehensive register of microclimate along an elevational gradient. The study, which spanned a 3900 m elevational gradient, confirmed the importance of the cloud regime on tree growth rates in tropical montane forests, as changes in the position of the cloud layer during the year led to variation in the amount of solar radiation reaching these forests. Separating the covariance of variable climatic changes along elevational gradients is extremely important to understanding how plants respond with changing climate, but studies like Rapp's (2010) have proved how limited research can be without microclimatic analysis. Nonetheless, even in the absence of microclimatic data, elevational gradients have provided significant insights into the importance of climate in driving forest dynamics by comparing productivity and carbon storage in forests with different mean temperatures.

In the most complete compilation of data on net primary productivity (NPP) for tropical forests, Clark et al. (2001) showed how most of the studies had focused on gathering information on stem productivity and rates of fine litterfall, but there is still a big gap of information on belowground variables such as volatile organic compounds, root losses to belowground consumers, root exudates, carbon export to symbionts 
(mycorrhizae, nodules) and root biomass. In the few studies looking at belowground variables, Vogt et al. (1995) investigated carbon allocation between aboveground and belowground biomass in tropical forests sites, finding that a variety of abiotic and biotic factors affected fine-root biomass and productivity at the community level. However, fine root biomass has rarely been assessed at the individual plant level (Jackson et al. 1996), and empirical data on the coarse-root incremental growth of tropical forests is also lacking (Girardin et al. 2010, Moser et al. 2011). This dearth of information on belowground biomass and productivity is perhaps most pronounced in tropical montane cloudforests. In this ecosystem, few studies have considered belowground net primary productivity and biomass and much remains unknown (Leuschner et al. 2007, Graefe et al. 2008a, Girardin et al. 2010, Moser et al. 2011).

The main goal of this study is to test the hypothesis that a shift in plant distribution in Andean montane forests is responsible for the pattern of increasing productivity with temperature by using two plant functional traits, root:shoot ratio and specific leaf area, along an elevational gradient. The field project of this study is developed in Chapter 2, which is written in a journal format to be submitted for publication.

\section{LITERATURE CITED}

AIBA, S. \& KITAYAMA, K. 1999. Structure , composition and species diversity in an altitude-substrate matrix of rain forest tree communities on Mount Kinabalu, Borneo. Plant Ecology 140:139-157. 
AINSWORTH, E. A. \& LONG, S. P. 2005. What have we learned from 15 years of freeair $\mathrm{CO} 2$ enrichment (FACE)? A meta-analytic review of the responses of photosynthesis, canopy properties and plant production to rising $\mathrm{CO} 2$. The New Phytologist 165:351-71.

ARONSON, E. L. \& MCNULTY, S. G. 2009. Appropriate experimental ecosystem warming methods by ecosystem, objective, and practicality. Agricultural and Forest Meteorology 149:1791-1799.

BUSH, M. B. 2002. Distributional change and conservation on the Andean flank: a palaeoecological perspective. Global Ecology and Biogeography 11:463-473.

BUSH, M. B., SILMAN, M. R. \& URREGO, D. H. 2004. 48,000 Years of Climate and Forest Change in a Biodiversity Hot Spot. Science (New York, N.Y.) 303:827-9.

BUYTAERT, W., CÉLLERI, R. \& TIMBE, L. 2009. Predicting climate change impacts on water resources in the tropical Andes: Effects of GCM uncertainty. Geophysical Research Letters 36:L07406.

CAIRNS, M. A., BROWN, S., HELMER, E. H. \& BAUMGARDNER, G. A. 1997. Root biomass allocation in the world's upland forests. Oecologia 111:1-11.

CAO, K.-F. \& OHKUBO, T. 1998. Allometry, root/shoot ratio and root architecture in understory saplings of deciduous dicotyledonous trees in central Japan. Ecological Research 13:217-227.

CHAPIN, F. S., ZAVALETA, E. S., EVINER, V. T., NAYLOR, R. L., VITOUSEK, P. M., REYNOLDS, H. L., HOOPER, D. U., LAVOREL, S., SALA, O. E., HOBBIE, S. E., MACK, M. C. \& DÍAZ, S. 2000. Consequences of changing biodiversity. Nature 405:234-42. Macmillan Magazines Ltd.

CLARK, D. A., BROWN, S., KICKLIGHTER. DAVID W. CHAMBERS, J. Q., THOMLINSON, J. R., NI, J. \& HOLLAND, E. A. 2001a. Net Primary Production in Tropical Forests: An Evaluation and Synthesis of Existing Field Data. Ecological Applications 11:371-384.

CLARK, D. A., BROWN, S., KICKLIGHTTER, D. W., CHAMBERS, J. Q., THOMLINSON, J. R. \& NI, J. 2001b. Measuring Net Primary Production in Forests: Concepts and Field Methods. Ecological Applications 11:356-370.

CORNELISSEN, J. H. C., LAVOREL, S., GARNIER, E., DÍAZ, S., BUCHMANN, N., GURVICH, D. E., REICH, P. B., STEEGE, H. TER, MORGAN, H. D., HEIJDEN, M. G. A. VAN DER, PAUSAS, J. G. \& POORTER, H. 2003. A handbook of protocols for standardised and easy measurement of plant functional traits worldwide. Australian Journal of Botany 51:335. 
DA COSTA, A. C. L., GALBRAITH, D., ALMEIDA, S., PORTELA, B. T. T., DA COSTA, M., SILVA JUNIOR, J. DE A., BRAGA, A. P., DE GONÇALVES, P. H. L., DE OLIVEIRA, A. A. R., FISHER, R., PHILLIPS, O. L., METCALFE, D. B., LEVY, P. \& MEIR, P. 2010. Effect of 7 yr of experimental drought on vegetation dynamics and biomass storage of an eastern Amazonian rainforest. The New phytologist 187:579-91.

DAY, M. E., GREENWOOD, M. S. \& DIAZ-SALA, C. 2002. Age- and size-related trends in woody plant shoot development: regulatory pathways and evidence for genetic control. Tree Physiology 22:507-13.

DELANEY, M., BROWN, S., LUGO, A. E., TORRES-LEZAMA, A. \& BELLO QUINTERO, N. 1997. The distribution of organic carbon in major components of forests located in five life zones of Venezuela. Journal of Tropical Ecology 13:697708.

ENQUIST, B. J. 2002. Universal scaling in tree and vascular plant allometry: toward a general quantitative theory linking plant form and function from cells to ecosystems. Tree physiology 22:1045-64.

FEELEY, K. J., REHM, E. M. \& MACHOVINA, B. 2012. Perspective: The responses of tropical forest species to global climate change: acclimate, adapt, migrate, or go extinct? Frontiers of Biogeography 4:69-84.

FEELEY, K. J. \& SILMAN, M. R. 2010a. Modelling the responses of Andean and Amazonian plant species to climate change: the effects of georeferencing errors and the importance of data filtering. Journal of Biogeography 37:733-740.

FEELEY, K. J. \& SILMAN, M. R. 2010b. Land-use and climate change effects on population size and extinction risk of Andean plants. Global Change Biology 16:3215-3222.

FEELEY, K. J., SILMAN, M. R., BUSH, M. B., FARFAN, W., CABRERA, K. G., MALHI, Y., MEIR, P., REVILLA, N. S., QUISIYUPANQUI, M. N. R. \& SAATCHI, S. 2011. Upslope migration of Andean trees. Journal of Biogeography 38:783-791.

FRAZER, G. W., CANHAM, C. D. \& LERTZMAN, K. P. 1999. Gap Light Analyzer (GLA), Version 2.0: Imaging software to extract canopy structure and gap light transmission indices from true-colour fisheye photographs, users manual and program documentation. Simon Fraser University, Burnaby, British Columbia, and the Institute of Ecosystem Studies, Millbrook, New York.

FRECKLETON, R. P. 2002. On the misuse of residuals in ecology: regression of residuals vs . multiple regression. Journal of Animal Ecology 71:542-545. 
GIBBON, A., SILMAN, M. R., MALHI, Y., FISHER, J. B., MEIR, P., ZIMMERMANN, M., DARGIE, G. C., FARFAN, W. R. \& GARCIA, K. C. 2010. Ecosystem Carbon Storage Across the Grassland-Forest Transition in the High Andes of Manu National Park, Peru. Ecosystems 13:1097-1111.

GIRARDIN, C. A. J., MALHI, Y., ARAGÃO, L. E. O. C., MAMANI, M., HUARACA HUASCO, W., DURAND, L., FEELEY, K. J., RAPP, J., SILVA-ESPEJO, J. E., SILMAN, M., SALINAS, N. \& WHITTAKER, R. J. 2010. Net primary productivity allocation and cycling of carbon along a tropical forest elevational transect in the Peruvian Andes. Global Change Biology 16:3176-3192.

GOLDSMITH, G. R., MATZKE, N. J. \& DAWSON, T. E. 2013. The incidence and implications of clouds for cloud forest plant water relations. Ecology letters 16:307314.

GRADSTEIN, S. R., HOMEIER, J. \& GANSERT, D. (Eds.). 2008. The Tropical Mountain Forest - Patterns and Processes in a Biodiversity Hotspot. P. 219. University of Göttingen.

GRAEFE, S., HERTEL, D. \& LEUSCHNER, C. 2008a. Fine root dynamics along a 2,000-m elevation transect in South Ecuadorian mountain rainforests. Plant and Soil 313:155-166.

GRAEFE, S., HERTEL, D. \& LEUSCHNER, C. 2008b. Estimating Fine Root Turnover in Tropical Forests along an Elevational Transect using Minirhizotrons. Biotropica 40:536-542.

GRECHI, I., VIVIN, P., HILBERT, G., MILIN, S., ROBERT, T. \& GAUDILLÈRE, J.P. 2007. Effect of light and nitrogen supply on internal C:N balance and control of root-to-shoot biomass allocation in grapevine. Environmental and Experimental Botany 59:139-149.

GRUBB, P. J. \& WHITMORE, T. C. 1967. A Comparison of Montane and Lowland Forest in Ecuador: III. The Light Reaching the Ground Vegetation. Journal of Ecology 55:33-57.

HERZOG, S. K., MARTÍNEZ, R., JØRGENSEN, P. M. \& TIESSEN, H. 2011. Climate Change and Biodiversity in the Tropical Andes Edited by. P. 348 (S. K. Herzog, R. Martínez, P. M. Jørgensen, and H. Tiessen, Eds.). Inter-American Institute of Global Change Research (IAI) and Scientific Committee on Problems of the Environment (SCOPE), São José dos Campos, Brazil and Paris, France.

HOFFMANN, W. A., FRANCO, A. C., MOREIRA, M. Z. \& HARIDASAN, M. 2005. Specific leaf area explains differences in leaf traits between congeneric savanna and forest trees. Functional Ecology 19:932-940. 
JACKSON, R. B., CANADELL, J., EHLERINGER, J. R., MOONEY, H. A., SALA, O. E. \& SCHULZE, E. D. 1996. A global analysis of root distributions for terrestrial biomes. Oecologia 108:389-411.

KATTGE, J., DÍAZ, S., LAVOREL, S., PRENTICE, I. C., LEADLEY, P., et al. 2011. TRY - a global database of plant traits. Global Change Biology 17:2905-2935.

KING, D. A. 1996. Allometry and Life History of Tropical Trees. Journal of Tropical Ecology 12:25-44. Cambridge University Press.

KING, D. A. \& CLARK, D. A. 2011. Allometry of emergent tree species from saplings to above-canopy adults in a Costa Rican rain forest. Journal of Tropical Ecology 27:573-579.

KITAYAMA, K. \& AIBA, S.-I. 2002. Ecosystem structure and productivity of tropical rain forests along altitudinal gradients with contrasting soil phosphorus pools on Mount Kinabalu, Borneo. Journal of Ecology 90:37-51.

KRAFT, N. J. B., VALENCIA, R. \& ACKERLY, D. D. 2008. Functional traits and niche-based tree community assembly in an Amazonian forest. Science (New York, N.Y.) $322: 580-2$.

LARSEN, T. H. 2012. Upslope Range Shifts of Andean Dung Beetles in Response to Deforestation: Compounding and Confounding Effects of Microclimatic Change. Biotropica 44:82-89.

LESICA, P. \& ANTIBUS, R. K. 1990. The Occurrence of Mycorrhizae in Vascular Epiphytes of Two Costa Rican Rain Forests. Biotropica 22:250-258.

LEUSCHNER, C., MOSER, G., BERTSCH, C., RÖDERSTEIN, M. \& HERTEL, D. 2007. Large altitudinal increase in tree root/shoot ratio in tropical mountain forests of Ecuador. Basic and Applied Ecology 8:219-230.

LONG, W., ZANG, R., SCHAMP, B. S. \& DING, Y. 2011. Within- and among-species variation in specific leaf area drive community assembly in a tropical cloud forest. Oecologia 167:1103-13.

MALHI, Y., SILMAN, M., SALINAS, N., BUSH, M., MEIR, P. \& SAATCHI, S. 2010. Introduction: Elevation gradients in the tropics: laboratories for ecosystem ecology and global change research. Global Change Biology 16:3171-3175. Blackwell Publishing Ltd.

METCAlfE, D. B., MEIR, P., ARAGÃO, L. E. O. C., COSTA, A. C. L., BRAGA, A. P., GONÇALVES, P. H. L., ATHAYDES SILVA JUNIOR, J., ALMEIDA, S. S., DAWSON, L. A., MALHI, Y. \& WILLIAMS, M. 2008. The effects of water 
availability on root growth and morphology in an Amazon rainforest. Plant and Soil 311:189-199.

MOKANY, K., RAISON, J. R. \& PROKUSHKIN, A. S. 2006. Critical analysis of root: shoot ratios in terrestrial biomes. Global Change Biology 12:84-96.

MOSER, G., LEUSCHNER, C., HERTEL, D., GRAEFE, S., SOETHE, N. \& IOST, S. 2011. Elevation effects on the carbon budget of tropical mountain forests (S Ecuador): the role of the belowground compartment. Global Change Biology 17:2211-2226.

MYERS, N., MITTERMEIER, R. A., MITTERMEIER, C. G., DA FONSECA, G. A. \& KENT, J. 2000. Biodiversity hotspots for conservation priorities. Nature 403:853-8.

NICOTRA, A. B., ATKIN, O. K., BONSER, S. P., DAVIDSON, A. M., FINNEGAN, E. J., MATHESIUS, U., POOT, P., PURUGGANAN, M. D., RICHARDS, C. L., VALLADARES, F. \& VAN KLEUNEN, M. 2010. Plant phenotypic plasticity in a changing climate. Trends in Plant Science 15:684-92.

PAINE, C. E. T., BARALOTO, C., CHAVE, J. \& HÉRAULT, B. 2011. Functional traits of individual trees reveal ecological constraints on community assembly in tropical rain forests. Oikos 120:720-727.

POORTER, H., NIKLAS, K. J., REICH, P. B., OLEKSYN, J., POOT, P. \& MOMMER, L. 2012. Biomass allocation to leaves, stems and roots: meta-analyses of interspecific variation and environmental control. The New Phytologist 193:30-50.

POORTER, H. \& VAN DER WERF, A. 1998. Is inherent variation in RGR determined by LAR at low irradiance and by NAR at high irradiance? a review of herbaceous species. Pp. 309-336 in Lambers, H., Poorter, H. \& Van Vuuren, M. M. I. (eds.). Inherent Variation in Plant Growth: Physiological Mechanisms and Ecological Consequences. Backhuys Publishers, Leiden, The Netherlands.

RAICH, J. W., RUSSELL, A. E. \& VITOUSEK, P. M. 1997. Primary productivity and ecosystem development along an elevational gradient on Mauna Loa, Hawai' $i$. Ecology 78:707-721.

RAPP, J. M. 2010. Climate control on plant performance across an Andean altitudinal gradient. Wake Forest University, Winston Salem, North Carolina, USA.

RAPP, J. M., SILMAN, M. R., CLARK, J. S., GIRARDIN, C. A. J., GALIANO, D. \& TITO, R. 2012. Intra- and inter-specific tree growth across a long altitudinal gradient in the Peruvian Andes. Ecology 93:2061-2072.

REICH, P. B. 1998. Variation among plant species in leaf turnover rates and associated traits: implications for growth at all life stages. Pp. 457-487 in Lambers, H., Poorter, 
H. \& Van Vuuren, M. M. I. (eds.). Inherent Variation in Plant Growth:

Physiological Mechanisms and Ecological Consequences. Backhuys Publishers, Leiden, The Netherlands.

REICH, P. B. \& SCHOETTLE, A. W. 1988. Role of phosphorus and nitrogen in photosynthetic and whole plant carbon gain and nutrient use efficiency in eastern white pine. Oecologia 77:25-33.

REICH, P. B., WALTERS, M. B. \& ELLSWORTH, D. S. 1992. Leaf Life-Span in Relation to Leaf, Plant, and Stand Characteristics among Diverse Ecosystems. Ecological Monographs 62:365.

REICH, P. B., WALTERS, M. B., TJOELKER, M. G., VANDERKLEIN, D. \& BUSCHENA, C. 1998. Photosynthesis and respiration rates depend on leaf and root morphology and nitrogen concentration in nine boreal tree species differing in relative growth rate. Functional Ecology 12:395-405.

RUSTAD, L., CAMPBELL, J., MARION, G., NORBY, R., MITCHELL, M., HARTLEY, A., CORNELISSEN, J. \& GUREVITCH, J. 2001. A meta-analysis of the response of soil respiration, net nitrogen mineralization, and aboveground plant growth to experimental ecosystem warming. Oecologia 126:543-562.

SHIPLEY, B., PAINE, C. E. T. \& BARALOTO, C. 2012. Quantifying the importance of local niche-based and stochastic processes to tropical tree community assembly. Ecology 93:760-9.

TANNER, E. V. J. 1998a. Experimental Investigation of Nutrient Limitation of Forest Growth on Wet Tropical Mountains. Ecology 79:10-22.

TANNER, E. V. J. 1998b. Studies on the Biomass and Productivity in a Series of Montane Rain Forests in Jamaica. Journal of Ecology 68:573-588.

TERBORGH, J. 1977. Bird species diversity on an Andean elevational gradient. Ecology 58:1007-1019.

VITOUSEK, P. M. \& HOWARTH, R. W. 2008. Nitrogen limitation on land and in the sea: How can it occur? 13:87-115.

VOGT, K. A., VOGT, D. J., PALMIOTTO, P. A., BOON, P., O'HARA, J. \& ASBJORNSEN, H. 1995. Review of root dynamics in forest ecosystems grouped by climate, climatic forest type and species. Plant and Soil 187:159-219.

WAIDE, R. B., ZIMMERMAN, J. K. \& SCATENA, F. N. 1998. Controls of primary productivity: lessons from the Luquillo Mountains in Puerto Rico. Ecology 79:3137. 
VAN DE WEG, M. J., MEIR, P., GRACE, J. \& ATKIN, O. K. 2009. Altitudinal variation in leaf mass per unit area, leaf tissue density and foliar nitrogen and phosphorus content along an Amazon-Andes gradient in Peru. Plant Ecology \& Diversity 2:243-254.

WEST, G. B., BROWN, J. H. \& ENQUIST, B. J. 1999. A general model for the structure and allometry of plant vascular systems 400:664-667.

WRIGHT, I. J., REICH, P. B., WESTOBY, M., ACKERLY, D. D., BARUCH, Z., BONGERS, F., CAVENDER-BARES, J., CHAPIN, T., CORNELISSEN, J. H. C., DIEMER, M., FLEXAS, J., GARNIER, E., GROOM, P. K., GULIAS, J., HIKOSAKA, K., LAMONT, B. B., LEE, T., LEE, W., LUSK, C., MIDGLEY, J. J., NAVAS, M.-L., NIINEMETS, U., OLEKSYN, J., OSADA, N., POORTER, H., POOT, P., PRIOR, L., PYANKOV, V. I., ROUMET, C., THOMAS, S. C., TJOELKER, M. G., VENEKLAAS, E. J. \& VILLAR, R. 2004a. The worldwide leaf economics spectrum. Nature 428:821-827.

WRIGHT, I. J. \& WESTOBY, M. 1999. Differences in seedling growth behaviour among species: trait correlations across species, and trait shifts along nutrient compared to rainfall gradients. Journal of Ecology 87:85-97.

WRIGHT, S. J., BUNKER, D., DALLING, J., DAVIES, S., DÍAZ, S., HARMS, K., KITAJIMA, K., KRAFT, N., MARKS, C., ENGELBRECHT, B., REICH, P., VALENCIA, R., WRIGHT, I. \& WRIGHT, J. 2004b. Towards a functional trait based research program within the Center for Tropical Forest Science. Pp. 1-15.

XIE, J., TANG, L., WANG, Z., XU, G. \& LI, Y. 2012. Distinguishing the biomass allocation variance resulting from ontogenetic drift or acclimation to soil texture. PloS one 7:e41502.

YOUNG, K. R. \& LEÓN, B. 1999. Peru's humid eastern montane forests: An overview of their physical settings, biological diversity, human use and settlement, and conservation needs. Centre for Research on the Cultural and Biological Diversity of Andean Rainforests (DIVA).

ZIMMERMANN, M., MEIR, P., SILMAN, M. R., FEDDERS, A., GIBBON, A., MALHI, Y., URREGO, D. H., BUSH, M. B., FEELEY, K. J., GARCIA, K. C., DARGIE, G. C., FARFAN, W. R., GOETZ, B. P., JOHNSON, W. T., KLINE, K. M., MODI, A. T., RURAU, N. M. Q., STAUDT, B. T. \& ZAMORA, F. 2009. No Differences in Soil Carbon Stocks Across the Tree Line in the Peruvian Andes. Ecosystems 13:62-74. 


\section{CHAPTER 2: ANALYZING ROOT:SHOOT RATIO AND SPECIFIC LEAF AREA IN A CLOUDFOREST ALONG AN ELEVATIONAL GRADIENT IN THE PERUVIAN ANDES}

\section{ABSTRACT}

For Andean montane ecosystems, especially cloudforests, there is limited understanding of the link between plant distribution and ecosystem productivity. In montane forests aboveground productivity is lower at higher elevations than lower elevations. Is this pattern in productivity due to species turnover along the elevational gradients? Due to the methodological approach used in montane forests, this question stated has not been fully tested. Also, despite their importance, most measurements of primary productivity to date have focused mainly on aboveground biomass, while biomass allocation belowground remains poorly quantified/understood. This study used two plant functional traits measured in congeneric individuals to elucidate if species turnover is responsible of the patterns in productivity seen in Andean montane forests. I collected 317 seedlings belonging to six species of trees along a $700 \mathrm{~m}$ elevational gradient (2700-3400 m asl) from a cloudforest located in the Peruvian Andes. Species collected were Clusia cf. alata, C. flaviflora, Symplocos psiloclada, S. quitensis, Weinmannia bangii, and $W$.

microphylla. Root:shoot ratios were measured as the dry mass of belowground over aboveground organs, and specific leaf area was measured as the area of a fresh leaf over its dry mass, for each seedling. For each seedling we also recorded data on elevation, light availability, and soil $\mathrm{pH}$. Allometric effects on plant traits were detected and taken 
into account later for analysis of plant functional traits using the basal diameter of seedlings. Root:shoot ratio increased with elevation in the case of $W$. microphylla, and decreased in C. flaviflora. Support for the hypothesis of a biomass pattern shift from aboveground to belowground with elevation only came from data for one species. Also, root:shoot ratio increased in places with higher values of canopy openness in $W$. microphylla, and higher soil $\mathrm{pH}$ values in S. quitensis. Specific leaf area increased with elevation in the case of $S$. quitensis, decreased in $S$. psiloclada, and showed a slight negative trend with elevation in the case of $W$. microphylla. Further, specific leaf area in S. quitensis decreased in areas with higher canopy openness. No directional changes with elevation were observed in root:shoot ratio and specific leaf area within species along the elevational gradient. A singular evidence of tradeoffs was found in the photosynthetic capacity with elevation. Lack of information on plant age could be a crucial factor complicating the analysis of environmental control along the elevational gradient. Therefore, our results cannot support or reject the hypothesis that shift in plant distribution affects ecosystem functioning.

\section{INTRODUCTION}

The Andean montane forests, which include the cloudforests, are perhaps one of the ecosystems that poses the greatest challenge in conservation due to human and climate impacts (Young \& León 1999). Paleoecological studies show that Andean forests responded to historic changes in temperatures with distributional shifts (Bush et al. 2004), however there is still great uncertainty about whether montane trees can migrate upslope 
and whether they can migrate at the pace imposed by current climate change (Feeley et al. 2011). In addition, it is possible that Andean montane forests will encounter climatic and human barriers to expansion above the treeline (Herzog et al. 2011). Moreover, species in the Andean montane forests exhibit narrow altitudinal home ranges, which makes these forests' biodiversity especially vulnerable in a scenario of climate change (Feeley \& Silman 2010a, Feeley et al. 2012), regardless of their past life-history traits. More research is needed to better understand and predict tree migration in the Andes, but also consequences of migration at the ecosystem and community level (e.g. nutrient cycling, biomass allocation, species interactions). Indeed, loss of diversity could cause disassembly at the community level and consequently compromise ecosystem functioning (Chapin et al. 2000).

The link between community assemblage and ecosystem productivity in Andean montane forests has only recently been addressed and many questions remain unexplored. Using elevational gradients, researchers have studied the effects of temperature on the structure and function of montane forests. These studies reported a clear decrease in productivity with elevation, consistently recording a decrease in tree height, aboveground biomass and ecosystem productivity with increasing elevation (Delaney et al. 1997, Kitayama \& Aiba 2002, Girardin et al. 2010). The few studies that have looked at belowground biomass report a reverse pattern on belowground biomass in comparison to the aboveground findings (Leuschner et al. 2007, Graefe et al. 2008b). The common method used in these studies encompassed the measure of biomass and carbon stocks at the plot level. However, this methodological approach does not consider species-specific contributions to the entire ecosystem production because analysis at the plot level 
includes a pool of different species. New studies that can consider the contribution of species are needed. These studies should examine whether the patterns in productivity observed in montane forest, i.e., lower aboveground productivity at higher than lower elevations, are due to species turnover between plots, intra-specific variation, or both? The pattern of decreasing forest productivity with temperature could be produced by a shift in the tree community at different elevations, and not only be a monotonic effect of temperature independent of species identity. Understanding what is causing these patterns could have important implications for prediction of carbon storage in these forests under global warming.

Beyond the question of what is driving the changes observed in productivity in the Andes, there is little information regarding belowground biomass. A shift in carbon allocation in trees from above ground to below ground has been hypothesized as the possible cause of decreasing aboveground biomass and increasing belowground carbon stocks with altitude (Zimmermann et al. 2009, Girardin et al. 2010). Few studies had focused their attention to belowground productivity. Studies looking at the belowground components of biomass have reported higher fine root carbon stocks and biomass in tropical montane forests than in lowland forests, and other studies along elevational gradients have reported increases in root biomass at higher elevations (Cairns et al. 1997, Leuschner et al. 2007, Graefe et al. 2008, Girardin et al. 2010, Moser et al. 2011). However the patterns remain poorly defined in cloudforests, with some studies showing contrasting patterns (Girardin et al. 2010). Furthermore, the cause of a shift towards increased belowground allocation at higher elevations has not been clarified yet. 
As for aboveground biomass, the estimates belowground in cloudforests or along elevational gradients come from measurements at the plot scale. For these measurements, bulk samples of roots were collected and measured without regard for which individual or species they belonged to, thereby producing single estimates of root biomass for large areas that may have encompassed hundreds of trees of dozens of species. As such, the basis for the purported shift in biomass allocation remains unclear.

One study in the Peruvian Andes looked at the connection between species distributional ecology and forest ecosystem using an elevational gradient. Rapp (2010) used a dominant and widespread genus of cloudforest trees in the Andes (Weinmannia spp.) to simultaneously study patterns of growth rate vs. elevation in multiple congeneric species across their altitudinal range. This study revealed that growth rates within species did not vary consistently with temperature but that between species there was a trade-off between growth rates and temperature niche. Specifically, species growing at lower elevations grew faster than their highland congeneric. This finding suggests that species turn-over is largely responsible for the positive correlation between productivity and temperature seen along elevational gradients. It remains unknown how this finding will hold in other plant functional traits in the species from montane forests. Moreover, linking the differences in growth rates with particular plant traits could be important to understand the different strategies observed in congeneric species.

Functional traits are recognizable features that are important for the growth, reproduction, and survival of individuals (Cornelissen et al. 2003, Wright et al. 2004a). Plant functional traits have been widely recognized as being very powerful and useful 
tools to solve questions related to population genetics (Nicotra et al. 2010), community phylogeny (Paine et al. 2011), niche evolution (Shipley et al. 2012), and functional ecology (Kraft et al. 2008). Given their recognized importance, there have been extensive efforts to develop global databases on plant traits and to standardize collecting protocols (Cornelissen et al. 2003, Kattge et al. 2011).

A recognized index used to characterize relative biomass allocation to aboveground vs. belowground tissue growth is the root:shoot ratio. Root:shoot ratios are potentially influenced by environmental conditions, but could also vary through the development of individuals and between species (Cornelissen et al. 2003). Studies of trunk allometry in trees indicate that trunk diameter is related to tree height, but also to crown width and crown environment (King 1996). At early stages, trunk diameter needs to provide the stability for the plant to grow and increases at a proportional rate with height; however, to maintain the constant stability as crown develops, trunk diameter needs to adjust based on crown weight and width (King \& Clark 2011). Knowledge of the allometric relationship is critical to understand how this could affect estimates of root:shoot ratios. Nevertheless, the general trend for woody plants is that root:shoot ratio decreases with size due to stronger stem development, as has been observed in experiments under controlled environments (Poorter et al. 2012). Root:shoot ratio has been previously used to test the shift of aboveground to belowground along elevational gradients (Mokany et al. 2006, Leuschner et al. 2007) as mentioned earlier on this document. 
On the other hand, leaf traits are considered useful to detect intraspecific and interspecific trait variation along environmental gradients (Poorter \& Van Der Werf 1998, van de Weg et al. 2009, Long et al. 2011). Specially leaf traits that consider mass are sensitive to climate and soil resources, associated with competitive strength, and important in determining the capacity for plants to acquire carbon (Wright \& Westoby 1999). A widely used leaf trait is specific leaf area (SLA). SLA shows the relationship between the area and the mass of a leaf and represents the photosynthetic surface area per unit investment in leaf tissue (Wright et al. 2004a). High SLA values correspond to thinner or less dense leaves, but also these characteristics can be associated with short leaf life-spans. Short-lived leaves are also less tough and concentrate fewer amounts of secondary compounds. Secondary compounds are important factors determining leaves longevity; high amounts of secondary compounds dilute the amount of tissue allocated to photosynthesis and consequently reduce the overall photosynthetic capacity (Reich et al. 1992) . Also, an inverse relationship between leaf life span and relative growth rate has been demonstrated in some tropical species, and carbon assimilation rate and mass-based concentrations of leaf nitrogen, phosphorus and calcium decrease with increased lifespan (Reich \& Schoettle 1988, Reich et al. 1992, Reich 1998). This data is consistent with the lower photosynthetic rate of higher altitude plants, with their thicker, longer-living leaves, which often have lower mass-based N concentrations (Tanner 1998a, van de Weg et al. 2009). Possible explanations for these characteristics in montane forests at higher elevations include reduced $\mathrm{N}$ supply caused by low mineralization rates produced for low temperatures, and water logging in cloudforests (Tanner 1998b). Also, a decrease in direct photosynthetic active radiation (PAR), but an increase in diffuse PAR (Leuschner 
et al. 2007) and in relative humidity (Grubb \& Whitmore 1967) are among the consequences of immersion in clouds in this ecosystems.

Cloudforests are located along dramatic elevational gradients on the eastern side of the Andes, are the higher habitats in montane forests, and present a key opportunity to study the link between climate and ecosystem function, including primary productivity. Elevational gradients have been widely applied in ecology as "natural laboratories" to help elucidate the responses of ecosystems to different environmental conditions. Historically, elevational gradients have been used as monotonic natural gradients in which habitat complexity, species richness, ecosystem productivity, and temperature all decline steadily with elevation (Terborgh 1977). More recently, scientists have begun employing natural elevational and environmental gradients as "space-for-time substitutions" that are helping our understanding of how climate changes could affect the global carbon budget, especially in areas such as tropical forests where it is extremely difficult to set up large scale manipulative experiments (Malhi et al. 2010).

Understanding the differences in growth and biomass allocation among different species from the Andean montane forests seems vital to infer the consequences of climate change on this ecosystem. Indeed, there is evidence that the pattern of increasing primary productivity with temperature is a consequence of a shift in plants distribution across elevation. This evidence could have serious implications on ecosystem productivity for the Andean montane forests because the increased productivity will depend on species migration. 


\section{Objectives}

Most studies conducted in Andean montane forests have focused exclusively on aboveground biomass estimations, and the importance of belowground stocks remains poorly quantified or understood (Clark et al. 2001b, Leuschner et al. 2007, Girardin et al. 2010). Elevational gradients in the tropical Andes provide a setting that can be used to test the effects of temperature and other climatic variables on plant responses, including belowground biomass allocation. Plant functional traits are also available tools to test these responses, and root:shoot ratio is one trait that reflects aspects of belowground biomass. The goals of this study were (1.) to analyze root:shoot ratios (RSR) of individual seedlings of dominant trees across an elevational gradient in the southern Peruvian Andes to determine if there is a shift in aboveground vs. belowground biomass allocation in relation to elevation; and (2.) to determine whether specific leaf area (SLA), a proxy for the potential photosynthetic capacity of species, changes with increasing elevation. If the analysis of plant functional traits shows a directional environmental filtering along the elevational gradient, I hypothesized that root:shoot ratios increase and SLA decreases within species with increasing elevation. To consider the inherent differences in plant traits among species, six species were sampled in this study. Moreover, tradeoffs across species in relation to root:shoot ratio or SLA were considered by using congeneric species. 


\section{METHODS}

Study site

Seedlings were collected from a ridge called Trocha Union along a $\sim 700 \mathrm{~m}$ altitudinal gradient $(2700-3442 \mathrm{~m}$ asl $)$ at the southern edge of Manu National Park in the head of the Kosñipata Valley $\left(-13^{\circ} 6^{\prime} 18^{\prime \prime}\right.$ latitude, $-71^{\circ} 35^{\prime} 21^{\prime \prime}$ longitude, datum WGS84). The top part of Trocha Union is located approximately $55 \mathrm{~km}$ northeast from the Department of Cusco (Peru) (Figure 1). The cool and wet climate at the study site supports a tropical montane cloudforest, and temperature decreases with altitude at a measured lapse rate of $-5.5^{\circ} \mathrm{C}$ per $1000 \mathrm{~m}$ of elevational gain (Bush et al. 2004, Feeley \& Silman 2010b). This study site is the focus of ongoing research by the Andes Biodiversity and Ecosystem Research Group (ABERG; http://andesresearch.org/), a multidisciplinary group of scientists from the USA, the UK, and Peru. ABERG has established a network of 211 ha vegetation monitoring plots ranging from 200 to $3500 \mathrm{~m}$ asl, centered on the Kosnipata Valley, Tono, and Tambopata valleys of southeastern Peru. In the Kosnipata Valley, the ABERG plots are separated by $\sim 250 \mathrm{~m}$ in altitude along the elevational gradient, from the lowlands (lowest plots at $300 \mathrm{~m}$ asl) to the elfin forest near the timberline (highest plots at $3450 \mathrm{~m}$ asl), and encompass a range of approximately $18^{\circ} \mathrm{C}$ mean annual temperature (Malhi et al. 2010). The present study along the $\sim 700 \mathrm{~m}$ elevational gradient covered the area around the four top ABERG plots, which is covered in cloudforests, with mean annual temperature ranging from $11.1^{\circ} \mathrm{C}$ at $2700 \mathrm{~m}$ asl to 7.7 ${ }^{\circ} \mathrm{C}$ at $3400 \mathrm{~m}$ asl (temperatures reported in Rapp et al. 2012). 
Rapp (2010) reports three distinct seasons for the study area: summer or wet season from November through March, April shows a short transition between wet and dry seasons, then winter or dry season from May to July, and spring or dry-wet transition from August to October. Also, the same study reports the patterns among seasons and across elevations of temperature, rain, photosynthetically active radiation (PAR), and humidity. Temperatures are higher in the wet season than in the dry season but the difference is less than $2^{\circ} \mathrm{C}$. Precipitation varies smoothly over the year, but reaches its maximum in January and February and its minimum in June and July; annual precipitation decreases linearly with elevation above $1000 \mathrm{~m}$ asl, with precipitation ranging from less than $1000 \mathrm{~mm} /$ year at 4130 meters to greater than $5000 \mathrm{~mm} /$ year at 890 meters. PAR decreases with altitude for most of the year, except during the dry season (April-July) when cloudiness is higher at lower altitudes and PAR shows a reversed pattern. Light levels decrease after the early wet season (November and December). Vapor pressure decreases with altitude, but maintains fairly consistent over the year, and between the canopy and understory. However, vapor pressure deficit (VPD) shows seasonal patterns, with low values in the wet season and reversing the pattern along the altitudinal gradient from the dry season to the dry-season transition.

The study site is immersed in a tropical montane cloudforest, where patterns of cloud formation are critical for determining the changes in microclimate variables, as mentioned in the paragraph above. During the dry season, the cloud base is located at lower altitudes, causing a general pattern of increased light with altitude and a relatively shallow adiabatic lapse rate. The dry-wet transition and wet season shows a reversed situation in which the cloud base is located at higher altitudes, with more light at lower 
altitudes, and the adiabatic lapse rate is steeper due to larger changes in temperature at lower elevations. During the day the gradient experiences upslope winds, and as the moist air rises, it condenses into clouds, such that light levels are lower in the afternoon than in the morning, and higher rainfall occurs in the afternoon (Rapp 2010).

The study site has a homogeneous geological substrate (Girardin et al. 2010) which is Paleozoic shale-slate. Soil carbon, nitrogen and phosphorus stocks in the top 50 $\mathrm{cm}$ are higher in the higher-elevation portions of the gradient, and the soil also has a thick layer of humic material (Zimmermann et al. 2009).

Seedling species collected

Between May and July 2011 (dry season), 317 seedlings from six species were collected from the understory of the study site. Species collected were Clusia cf. alata, $C$. flaviflora, Symplocos psiloclada, S. quitensis, Weinmannia bangii, and W. microphylla (Figure 2). The selected species represent some of the most common and dominant tree species found in the forests at these elevations (Table 1). At the genus level, Weinmannia is the most dominant genus among the ABERG plots, accounting for the $16 \%$ of woody stems $\geq 10 \mathrm{~cm}$ dbh (diameter at breast height), and Clusia accounts for 13\% (0.3-43.5\% of stems per plot) (Rapp et al. 2012).

Seedlings were located in the field through directed searches along the trails and in accessible areas of forest, focusing on the forests adjacent to the top four higherelevation ABERG plots. The range of elevation where each seedling species was 
collected is shown in Figure 3. The most abundant and widespread species recorded for this study were C. alata $(\mathrm{n}=77)$, Weinmannia microphylla $(\mathrm{n}=63)$, and $S$. psiloclada $(\mathrm{n}=61) ;$. flaviflora $(\mathrm{n}=33)$, S. quitensis $(\mathrm{n}=46)$, and $W$. bangii $(\mathrm{n}=37)$ were less common.

Individuals smaller than $100 \mathrm{~cm}$ in height and less than $1 \mathrm{~cm}$ of basal diameter were considered seedlings. Only seedlings having their roots in the ground were considered in the study; many seedlings in the study area had roots that were positioned in the moss layer only, and those were not included in the sampling. The collected seedlings ranged from 1.35 to $8.19 \mathrm{~mm}$ in basal diameter and 8 to $82 \mathrm{~cm}$ in height (Figure 4 \& Figure 5). Before removing the seedling from the ground, the point on the shoot right at the ground level was marked to be the division between shoot and root. Then seedlings were collected from the ground by carefully removing their roots from the soil using small spades and hands. Basal diameter was measured at the mark on the shoot at the root/shoot division. Shoot length was measured from the shoot base to the apical bud (tip of the shoot). Finally, the number of leaves was recorded.

\section{Canopy pictures and soil samples}

Once an individual of a focal species was located, its geographic coordinates and elevation were determined using a GPS unit (datum WGS84, Garmin GPSMAP 78s hand-held; Garmin International, Kansas USA). A hemispherical canopy photograph was taken immediately above the seedling using a digital camera (Nikon Coolpix P80) 
equipped with lens (Opteka 0.35x High Definition II Wide Angle Panoramic Macro). Canopy photographs were later analyzed with the freely-available Gap Light Analyzer program (GLA) (Frazer et al. 1999) to determine percent canopy openness (i.e., the percentage of sky visible above the seedling), which was used as a measurement for light availability.

A soil sample was collected for a subsample of seedlings by removing soil from the cavity left after each seedling was excavated. Zimmermann et al. (2009) estimated that the organic forest layer in the study area has a depth of between $20-70 \mathrm{~cm}$, and for this study any cavity left by the seedlings was not deeper than $70 \mathrm{~cm}$. To prepare the soil for taking $\mathrm{pH}$ measurements, plant debris, roots, leaves, and mosses were removed, then the soil was homogenized. Finally, two grams of each soil sample was mixed with $2 \mathrm{ml}$ of distilled water and the soil $\mathrm{pH}$ was measured with a portable Soil Stik $\mathrm{pH}$ meter (FieldScout, model 2105). The remaining soil from each sample was dried and saved for later nutrient analyses.

\section{Biomass analysis}

All collected seedlings were divided into leaves, stem, fine-roots $(<2 \mathrm{~mm}$ diameter), and coarse-roots ( $\geq 2 \mathrm{~mm}$ diameter) (Cornelissen et al. 2003). The plant parts were placed in paper envelopes and oven-dried at $60^{\circ} \mathrm{C}$ for 72 hours. The mass of each plant part was determined using a Pesola digital pocket scale (500 g Model, $\pm 0.1 \mathrm{~g}$

precision). The root:shoot ratio of each individual was calculated by dividing the mass of 
roots (fine and course roots combined) by the mass of the aboveground tissues (leaves and stems combined).

\section{Leaf analysis}

Leaves were separated from the plants after seedlings were collected. Cut leaves were individually wrapped in envelopes and placed in sealed plastic bags to maintain the leaves as water-saturated as possible. Also, the near-freezing temperatures that occurred naturally at the study site helped to maintain the leaves in good conditions until analysis. Leaves were inspected to detect any sign of decomposition and were discarded if necessary, although their weight was included for biomass analysis. One fully-expanded and non-damaged leaf was selected from each seedling for measurement. The area of each selected leaf was determined by scanning the fresh leaf along with a scale bar and analyzing the image using the Image $\mathrm{J}$ image analysis program (version $1.4638 \mathrm{x}, \mathrm{NIH}$, USA). For the mass measurement, the leaves were then oven-dried at a constant temperature of $60^{\circ} \mathrm{C}$ for 48 hours before their weight was determined using a digital balance (Ohaus Scout Pro, capacity 120g, precision $\pm 0.001 \mathrm{~g}$ ).

Specific leaf area (SLA, $\mathrm{mm}^{2} \mathrm{mg}^{-1}$ ) was calculated by dividing the fresh leaf area by its dry mass (Cornelissen et al. 2003). Petioles and rachises were considered part of the leaves as per guidelines for standardized SLA measurements. 


\section{Statistical Analysis}

Pearson correlation was used to measure the strength of the linear dependence among elevation and the other environmental variables (light availability, $\mathrm{pH}$ ). Linear regression analyses were used to quantify the effects of elevational gradients on root/shoot ratios and SLA, as well as environmental variables (light availability, $\mathrm{pH}$ ). In order to first control for the effects of size or ontogeny (Hoffmann et al. 2005) on the measured plant traits, linear regressions were performed using the residuals of regressions between root:shoot ratio and specific leaf area versus seedling diameter and height. The use of residuals as data, although arguable, is common especially in controlling for the effect of size (Freckleton 2002) and is functionally equivalent to a partial regression.

\section{RESULTS}

Shoot height and basal diameter were significantly correlated across all the focal species (Figure 6), although correlations were weak among some species. Height did not show a significant relationship with root:shoot ratio in any of the species (Figure 7) but showed a significant positive relationship with specific leaf area in $S$. psiloclada $(\mathrm{p}=0.02)$ (Figure 9). Although not significant, a similar positive trend was found between specific leaf area and height in W. bangii; whereas a negative trend was found in C. alata (Figure 9). Specific leaf area did not show a significant relationship with diameter in any of the species (Figure 10), but a negative trend was found in C. alata and S. quitensis, and a positive trend in $W$. bangii. On the other hand, a significant positive relationship was 
found between root:shoot ratio and basal diameter in the species $W$. bangii $(\mathrm{p}=0.02)$

(Figure 8). Although not significant, a similar positive trend was found in W. microphylla and S. quitensis, whereas a negative trend was found in S. psiloclada (Figure 8). Overall, basal diameter was a better predictor of the effects of size in the traits. Henceforth, we used the trait (root:shoot ratio and specific leaf area) residuals from the correlations with basal diameter to test the relationship with the environmental variables (elevation, canopy openness, and $\mathrm{pH}$ ).

Root:shoot ratio analysis and elevation

The response of root:shoot ratio with elevation was different across species. Root:shoot ratio showed a significant positive relationship with elevation in the case of W. microphylla $(\mathrm{p}=0.06)$, and a significant negative relationship with C. flaviflora $(\mathrm{p}$ $=0.007)$. For $W$. bangii, C. alata, S. quitensis and $S$. psiloclada, the root: shoot ratio did not show any significant trend with elevation and remained constant across elevations ( $\mathrm{p}=$ $0.43,0.50,0.95$, and 0.26 respectively) (Figure 11).

Specific leaf area and elevation

The response of specific leaf area with elevation was different across species. Specific leaf area showed a significant positive relationship with elevation in the case of S. quitensis, and a significant negative relationship in the congeneric S. psiloclada 
$(p=0.000)$. Although not significant, a slight negative trend was also shown in the case of W. microphylla $(\mathrm{p}=0.07)$. In contrast, for $W$. bangii, C. alata and C. flaviflora there was no significant trend with elevation, and specific leaf area remained constant across elevations (Figure 12).

Plant functional traits and canopy openness

Canopy openness did not show any trend across elevations, but ranged from 5\% to $46 \%$, with an average of $10.5 \%$ across the analyzed gradient $( \pm 5.6, n=190$ pictures taken) (Figure 13). Overall, canopy openness was not a good predictor for the plant functional traits across species. However, root:shoot ratio in $W$. microphylla showed a significant positive relationship with canopy openness ( $\mathrm{p}=0.0007)$ (Figure 14). Further, specific leaf area in S. quitensis showed a significant negative relationship with canopy openness $(\mathrm{p}=0.04)$ (Figure 15).

Plant functional traits and $\mathrm{pH}$

Soil $\mathrm{pH}$ did not show any trend across elevations, ranged from 2.4 to 4.0 and showed an average of 3.1 across the analyzed gradient ( $\pm 0.5, \mathrm{n}=119$ seedlings) (Figure 16). Overall, soil $\mathrm{pH}$ was not a good predictor for the plant functional traits, and showed no significant relationship with specific leaf area across any species (Figure 18). 
However, soil $\mathrm{pH}$ in $S$. quitensis showed a significant positive relationship ( $\mathrm{p}=0.045)$ (Figure 17).

Correlation among environmental variables

No strong correlation was found among elevation, $\mathrm{pH}$ or canopy openness (Table 2).

\section{DISCUSSION}

Root:shoot ratio and specific leaf area, the plant functional traits in this study, were used to test the effects of temperature, canopy openness and soil $\mathrm{pH}$ in the biomass allocation of cloudforest tree seedlings. Biomass allocation is the relative partitioning of biomass among the different plant organs, and may vary over time, across environments and among species (Poorter et al. 2012). To understand whether variation in root:shoot ratio and specific leaf area are due to environment, the effects of size were evaluated by species using the shoot height and basal diameter.

Size influences not only the structural characteristics of plants, but also their functional features (West et al. 1999). Root:shoot ratio generally decreases with size in woody plants because plants have to invest in support tissue to grow, moreover plants increase in diameter as they grow in height (King 1996); in the case of specific leaf area, no clear relationship with size is known. Although the allometric relationship between height and basal diameter is widely recognized in adult plants, it has shown to be more 
variable in tree seedlings (Poorter et al. 2012). In this study significant relationships were found between basal diameter and height across species; however, strong correlations were not found in some species. Basal diameter was used to analyze the effects of plant size in both plant traits. Analysis of root:shoot ratio and specific leaf area across elevations were performed using the residuals of previous regressions with basal diameter. However, the potential effect of age cannot be discarded, and this variable has been found to have an important effect in biomass allocation. Due to the scope of the study, no further conclusions can be drawn regarding age control. A study in cotton plants showed that biomass allocation to metabolically active organs (roots and leaves) is mainly controlled by environmental factors, and allocation to metabolically non-active organs (stems) was mainly governed by ontogenetic drift (Xie et al. 2012). This hypothesis has not been tested on this study.

Three pairs of congeneric species were used to evaluate the intraspecific and interspecific trait variation and detect possible tradeoffs in strategies along the environmental gradients. Only two species showed a directional change with elevation in biomass allocation. Mostly, results of root:shoot ratios within species illustrates plasticity and make evident that elevation (used as proxy for temperature) does not show a strong control in biomass allocation. Furthermore, there is no strong evidence of a shift between aboveground to belowground biomass as shown in other elevational gradients in montane forests (Leuschner et al. 2007). The difference could be in the methods used. In the Ecuadorian study, root tissue was divided in live and dead roots, and roots were sampled using soil cores instead of harvesting entire plants as here in this study. However, there is some evidence that temperature does not control growth and productivity strongly within 
the cloud immersion zone (Rapp 2010, Girardin et al. 2010). Hence, we can suggest that biomass allocation is not directly controlled by temperature in the upper reaches of the elevational gradient and that possibly within the cloud zone temperature plays a mixed role with air humidity and water availability in the soil. An interesting recent finding is that foliar water uptake is likely to be a widespread phenomenon in cloudforests trees, nonetheless the capacity differs significantly between the montane and pre-montane forest plant communities, as well as among species within a forest (Goldsmith et al. 2013). The capacity of some plants to "drink water" through their leaves is known to have an effect in root length, that accordingly could impact biomass allocation (Metcalfe et al. 2008).

With respect to the belowground biomass, mycorrhizae are a possible missing piece in the belowground budget on this study. Mycorrhizae do occur in montane forests and seemingly are just as ubiquitous as they are in lowland forests (Lesica \& Antibus 1990). Little information are available, which potentially represents a real difficulty for studies of carbon allocation (Clark et al. 2001b).

In the specific leaf area analysis, lower values with increasing elevation were expected (thicker, longer-living leaves). Similarly, no directional changes with elevation were found within species. However, two species, S. quitensis, and S. psiloclada, showed evidence of tradeoff across elevations. In the first case, $S$. quitensis presented an opposite trend to that expected in leaves from cloudforest plants, as SLA increased with elevation. On the other hand, S. psiloclada showed the expected strategy in cloudforests. Seedlings of $S$. quitensis were found in places with a higher percentage of canopy openness; this 
possibly provides evidence for tradeoff in photosynthetic capacity with light partitioning along the elevational gradient.

Finally, to fully understand or make conclusions about the effects of ontogeny on plant functional traits, not only is physiological information on photosynthesis and respiration needed but also more specific detailed plant morphological models are required (Day et al. 2002). I propose four models that possibly explain the relationship between genetics, age, and environmental control over traits. According to these models: 1. A fully developed organ can be modified by an environmental stimulus; 2. meristems remain the same over time but are produced with developmental plasticity to respond to environmental stimulus if necessary; 3 . meristems are genetically controlled and their potential changes during the plant life cycle, which means that over time and with plant size, tissues are intrinsically different; 4 .as individuals age, there is a differential genetic response by meristems to environmental stimulus. As mentioned before, testing the effects that ontogeny could have on the measured plant traits was out of the scope of this study; an experimental approach will be needed to perform such tests; therefore, how changes along the development of the plants affect our results cannot be fully clarified.

\section{CONCLUSIONS}

No strong evidence of species turnover in juvenile plants along the elevational gradient was found. While temperature has been shown to be a good predictor at a large 
scale, within the cloud region it is possible that other environmental variables are acting in conjunction with temperature to determine growth and biomass allocation strategies.

Even with the limited scope of this study, it is important to consider potential impacts at the community level. If species at the study site have a biomass allocation strategy similar to W. microphylla, with higher belowground biomass at higher elevations, estimates of belowground biomass for cloudforest are missing a very important component of the carbon budget. This study reaffirms the importance of including roots to obtain more comprehensive studies of biomass or productivity. Moreover, there is a need for a better understanding of root biomass and water use in cloudforests to improve ecological models of climate change.

\section{LITERATURED CITED}

AIBA, S. \& KITAYAMA, K. 1999. Structure, composition and species diversity in an altitude-substrate matrix of rain forest tree communities on Mount Kinabalu, Borneo. Plant Ecology 140:139-157.

AINSWORTH, E. A. \& LONG, S. P. 2005. What have we learned from 15 years of freeair $\mathrm{CO} 2$ enrichment (FACE)? A meta-analytic review of the responses of photosynthesis, canopy properties and plant production to rising $\mathrm{CO} 2$. The New Phytologist 165:351-71.

ARONSON, E. L. \& MCNULTY, S. G. 2009. Appropriate experimental ecosystem warming methods by ecosystem, objective, and practicality. Agricultural and Forest Meteorology 149:1791-1799.

BUSH, M. B. 2002. Distributional change and conservation on the Andean flank: a palaeoecological perspective. Global Ecology and Biogeography 11:463-473.

BUSH, M. B., SILMAN, M. R. \& URREGO, D. H. 2004. 48,000 Years of Climate and Forest Change in a Biodiversity Hot Spot. Science (New York, N.Y.) 303:827-9. 
BUYTAERT, W., CÉLLERI, R. \& TIMBE, L. 2009. Predicting climate change impacts on water resources in the tropical Andes: Effects of GCM uncertainty. Geophysical Research Letters 36:L07406.

CAIRNS, M. A., BROWN, S., HELMER, E. H. \& BAUMGARDNER, G. A. 1997. Root biomass allocation in the world's upland forests. Oecologia 111:1-11.

CAO, K.-F. \& OHKUBO, T. 1998. Allometry, root/shoot ratio and root architecture in understory saplings of deciduous dicotyledonous trees in central Japan. Ecological Research 13:217-227.

CHAPIN, F. S., ZAVALETA, E. S., EVINER, V. T., NAYLOR, R. L., VITOUSEK, P. M., REYNOLDS, H. L., HOOPER, D. U., LAVOREL, S., SALA, O. E., HOBBIE, S. E., MACK, M. C. \& DÍAZ, S. 2000. Consequences of changing biodiversity. Nature 405:234-42. Macmillan Magazines Ltd.

CLARK, D. A., BROWN, S., KICKLIGHTER. DAVID W. CHAMBERS, J. Q., THOMLINSON, J. R., NI, J. \& HOLLAND, E. A. 2001a. Net Primary Production in Tropical Forests: An Evaluation and Synthesis of Existing Field Data. Ecological Applications 11:371-384.

CLARK, D. A., BROWN, S., KICKLIGHTTER, D. W., CHAMBERS, J. Q., THOMLINSON, J. R. \& NI, J. 2001b. Measuring Net Primary Production in Forests: Concepts and Field Methods. Ecological Applications 11:356-370.

CORNELISSEN, J. H. C., LAVOREL, S., GARNIER, E., DÍAZ, S., BUCHMANN, N., GURVICH, D. E., REICH, P. B., STEEGE, H. TER, MORGAN, H. D., HEIJDEN, M. G. A. VAN DER, PAUSAS, J. G. \& POORTER, H. 2003. A handbook of protocols for standardised and easy measurement of plant functional traits worldwide. Australian Journal of Botany 51:335.

DA COSTA, A. C. L., GALBRAITH, D., ALMEIDA, S., PORTELA, B. T. T., DA COSTA, M., SILVA JUNIOR, J. DE A., BRAGA, A. P., DE GONÇALVES, P. H. L., DE OLIVEIRA, A. A. R., FISHER, R., PHILLIPS, O. L., METCALFE, D. B., LEVY, P. \& MEIR, P. 2010. Effect of $7 \mathrm{yr}$ of experimental drought on vegetation dynamics and biomass storage of an eastern Amazonian rainforest. The New phytologist 187:579-91.

DAY, M. E., GREENWOOD, M. S. \& DIAZ-SALA, C. 2002. Age- and size-related trends in woody plant shoot development: regulatory pathways and evidence for genetic control. Tree Physiology 22:507-13.

DELANEY, M., BROWN, S., LUGO, A. E., TORRES-LEZAMA, A. \& BELLO QUINTERO, N. 1997. The distribution of organic carbon in major components of forests located in five life zones of Venezuela. Journal of Tropical Ecology 13:697708. 
ENQUIST, B. J. 2002. Universal scaling in tree and vascular plant allometry: toward a general quantitative theory linking plant form and function from cells to ecosystems. Tree physiology 22:1045-64.

FEELEY, K. J., REHM, E. M. \& MACHOVINA, B. 2012. Perspective: The responses of tropical forest species to global climate change: acclimate, adapt, migrate, or go extinct? Frontiers of Biogeography 4:69-84.

FEELEY, K. J. \& SILMAN, M. R. 2010a. Modelling the responses of Andean and Amazonian plant species to climate change: the effects of georeferencing errors and the importance of data filtering. Journal of Biogeography 37:733-740.

FEELEY, K. J. \& SILMAN, M. R. 2010b. Land-use and climate change effects on population size and extinction risk of Andean plants. Global Change Biology 16:3215-3222.

FEELEY, K. J., SILMAN, M. R., BUSH, M. B., FARFAN, W., CABRERA, K. G., MALHI, Y., MEIR, P., REVILLA, N. S., QUISIYUPANQUI, M. N. R. \& SAATCHI, S. 2011. Upslope migration of Andean trees. Journal of Biogeography 38:783-791.

FRAZER, G. W., CANHAM, C. D. \& LERTZMAN, K. P. 1999. Gap Light Analyzer (GLA), Version 2.0: Imaging software to extract canopy structure and gap light transmission indices from true-colour fisheye photographs, users manual and program documentation. Simon Fraser University, Burnaby, British Columbia, and the Institute of Ecosystem Studies, Millbrook, New York.

FRECKLETON, R. P. 2002. On the misuse of residuals in ecology: regression of residuals vs . multiple regression. Journal of Animal Ecology 71:542-545.

GIBBON, A., SILMAN, M. R., MALHI, Y., FISHER, J. B., MEIR, P., ZIMMERMANN, M., DARGIE, G. C., FARFAN, W. R. \& GARCIA, K. C. 2010. Ecosystem Carbon Storage Across the Grassland-Forest Transition in the High Andes of Manu National Park, Peru. Ecosystems 13:1097-1111.

GIRARDIN, C. A. J., MALHI, Y., ARAGÃO, L. E. O. C., MAMANI, M., HUARACA HUASCO, W., DURAND, L., FEELEY, K. J., RAPP, J., SILVA-ESPEJO, J. E., SILMAN, M., SALINAS, N. \& WHITTAKER, R. J. 2010. Net primary productivity allocation and cycling of carbon along a tropical forest elevational transect in the Peruvian Andes. Global Change Biology 16:3176-3192.

GOLDSMITH, G. R., MATZKE, N. J. \& DAWSON, T. E. 2013. The incidence and implications of clouds for cloud forest plant water relations. Ecology letters 16:307314. 
GRADSTEIN, S. R., HOMEIER, J. \& GANSERT, D. (Eds.). 2008. The Tropical Mountain Forest - Patterns and Processes in a Biodiversity Hotspot. P. 219. University of Göttingen.

GRAEFE, S., HERTEL, D. \& LEUSCHNER, C. 2008a. Fine root dynamics along a 2,000-m elevation transect in South Ecuadorian mountain rainforests. Plant and Soil 313:155-166.

GRAEFE, S., HERTEL, D. \& LEUSCHNER, C. 2008b. Estimating Fine Root Turnover in Tropical Forests along an Elevational Transect using Minirhizotrons. Biotropica 40:536-542.

GRECHI, I., VIVIN, P., HILBERT, G., MILIN, S., ROBERT, T. \& GAUDILLÈRE, J.P. 2007. Effect of light and nitrogen supply on internal C:N balance and control of root-to-shoot biomass allocation in grapevine. Environmental and Experimental Botany 59:139-149.

GRUBB, P. J. \& WHITMORE, T. C. 1967. A Comparison of Montane and Lowland Forest in Ecuador: III. The Light Reaching the Ground Vegetation. Journal of Ecology 55:33-57.

HERZOG, S. K., MARTÍNEZ, R., JØRGENSEN, P. M. \& TIESSEN, H. 2011. Climate Change and Biodiversity in the Tropical Andes Edited by. P. 348 (S. K. Herzog, R. Martínez, P. M. Jørgensen, and H. Tiessen, Eds.). Inter-American Institute of Global Change Research (IAI) and Scientific Committee on Problems of the Environment (SCOPE), São José dos Campos, Brazil and Paris, France.

HOFFMANN, W. A., FRANCO, A. C., MOREIRA, M. Z. \& HARIDASAN, M. 2005. Specific leaf area explains differences in leaf traits between congeneric savanna and forest trees. Functional Ecology 19:932-940.

JACKSON, R. B., CANADELL, J., EHLERINGER, J. R., MOONEY, H. A., SALA, O. E. \& SCHULZE, E. D. 1996. A global analysis of root distributions for terrestrial biomes. Oecologia 108:389-411.

KATTGE, J., DÍAZ, S., LAVOREL, S., PRENTICE, I. C., LEADLEY, P., et al. 2011. TRY - a global database of plant traits. Global Change Biology 17:2905-2935.

KING, D. A. 1996. Allometry and Life History of Tropical Trees. Journal of Tropical Ecology 12:25-44. Cambridge University Press.

KING, D. A. \& CLARK, D. A. 2011. Allometry of emergent tree species from saplings to above-canopy adults in a Costa Rican rain forest. Journal of Tropical Ecology 27:573-579. 
KITAYAMA, K. \& AIBA, S.-I. 2002. Ecosystem structure and productivity of tropical rain forests along altitudinal gradients with contrasting soil phosphorus pools on Mount Kinabalu, Borneo. Journal of Ecology 90:37-51.

KRAFT, N. J. B., VALENCIA, R. \& ACKERLY, D. D. 2008. Functional traits and niche-based tree community assembly in an Amazonian forest. Science (New York, N.Y.) $322: 580-2$.

LARSEN, T. H. 2012. Upslope Range Shifts of Andean Dung Beetles in Response to Deforestation: Compounding and Confounding Effects of Microclimatic Change. Biotropica 44:82-89.

LESICA, P. \& ANTIBUS, R. K. 1990. The Occurrence of Mycorrhizae in Vascular Epiphytes of Two Costa Rican Rain Forests. Biotropica 22:250-258.

LEUSCHNER, C., MOSER, G., BERTSCH, C., RÖDERSTEIN, M. \& HERTEL, D. 2007. Large altitudinal increase in tree root/shoot ratio in tropical mountain forests of Ecuador. Basic and Applied Ecology 8:219-230.

LONG, W., ZANG, R., SCHAMP, B. S. \& DING, Y. 2011. Within- and among-species variation in specific leaf area drive community assembly in a tropical cloud forest. Oecologia 167:1103-13.

MALHI, Y., SILMAN, M., SALINAS, N., BUSH, M., MEIR, P. \& SAATCHI, S. 2010. Introduction: Elevation gradients in the tropics: laboratories for ecosystem ecology and global change research. Global Change Biology 16:3171-3175. Blackwell Publishing Ltd.

METCALFE, D. B., MEIR, P., ARAGÃO, L. E. O. C., COSTA, A. C. L., BRAGA, A. P., GONÇALVES, P. H. L., ATHAYDES SILVA JUNIOR, J., ALMEIDA, S. S., DAWSON, L. A., MALHI, Y. \& WILLIAMS, M. 2008. The effects of water availability on root growth and morphology in an Amazon rainforest. Plant and Soil 311:189-199.

MOKANY, K., RAISON, J. R. \& PROKUSHKIN, A. S. 2006. Critical analysis of root: shoot ratios in terrestrial biomes. Global Change Biology 12:84-96.

MOSER, G., LEUSCHNER, C., HERTEL, D., GRAEFE, S., SOETHE, N. \& IOST, S. 2011. Elevation effects on the carbon budget of tropical mountain forests (S Ecuador): the role of the belowground compartment. Global Change Biology 17:2211-2226.

MYERS, N., MITTERMEIER, R. A., MITTERMEIER, C. G., DA FONSECA, G. A. \& KENT, J. 2000. Biodiversity hotspots for conservation priorities. Nature 403:853-8. 
NICOTRA, A. B., ATKIN, O. K., BONSER, S. P., DAVIDSON, A. M., FINNEGAN, E. J., MATHESIUS, U., POOT, P., PURUGGANAN, M. D., RICHARDS, C. L., VALLADARES, F. \& VAN KLEUNEN, M. 2010. Plant phenotypic plasticity in a changing climate. Trends in Plant Science 15:684-92.

PAINE, C. E. T., BARALOTO, C., CHAVE, J. \& HÉRAULT, B. 2011. Functional traits of individual trees reveal ecological constraints on community assembly in tropical rain forests. Oikos 120:720-727.

POORTER, H., NIKLAS, K. J., REICH, P. B., OLEKSYN, J., POOT, P. \& MOMMER, L. 2012. Biomass allocation to leaves, stems and roots: meta-analyses of interspecific variation and environmental control. The New Phytologist 193:30-50.

POORTER, H. \& VAN DER WERF, A. 1998. Is inherent variation in RGR determined by LAR at low irradiance and by NAR at high irradiance? a review of herbaceous species. Pp. 309-336 in Lambers, H., Poorter, H. \& Van Vuuren, M. M. I. (eds.). Inherent Variation in Plant Growth: Physiological Mechanisms and Ecological Consequences. Backhuys Publishers, Leiden, The Netherlands.

RAICH, J. W., RUSSELL, A. E. \& VITOUSEK, P. M. 1997. Primary productivity and ecosystem development along an elevational gradient on Mauna Loa, Hawai' $i$. Ecology 78:707-721.

RAPP, J. M. 2010. Climate control on plant performance across an Andean altitudinal gradient. Wake Forest University, Winston Salem, North Carolina, USA.

RAPP, J. M., SILMAN, M. R., CLARK, J. S., GIRARDIN, C. A. J., GALIANO, D. \& TITO, R. 2012. Intra- and inter-specific tree growth across a long altitudinal gradient in the Peruvian Andes. Ecology 93:2061-2072.

REICH, P. B. 1998. Variation among plant species in leaf turnover rates and associated traits: implications for growth at all life stages. Pp. 457-487 in Lambers, H., Poorter, H. \& Van Vuuren, M. M. I. (eds.). Inherent Variation in Plant Growth:

Physiological Mechanisms and Ecological Consequences. Backhuys Publishers, Leiden, The Netherlands.

REICH, P. B. \& SCHOETTLE, A. W. 1988. Role of phosphorus and nitrogen in photosynthetic and whole plant carbon gain and nutrient use efficiency in eastern white pine. Oecologia 77:25-33.

REICH, P. B., WALTERS, M. B. \& ELLSWORTH, D. S. 1992. Leaf Life-Span in Relation to Leaf, Plant, and Stand Characteristics among Diverse Ecosystems. Ecological Monographs 62:365.

REICH, P. B., WALTERS, M. B., TJOELKER, M. G., VANDERKLEIN, D. \& BUSCHENA, C. 1998. Photosynthesis and respiration rates depend on leaf and root 
morphology and nitrogen concentration in nine boreal tree species differing in relative growth rate. Functional Ecology 12:395-405.

RUSTAD, L., CAMPBELL, J., MARION, G., NORBY, R., MITCHELL, M., HARTLEY, A., CORNELISSEN, J. \& GUREVITCH, J. 2001. A meta-analysis of the response of soil respiration, net nitrogen mineralization, and aboveground plant growth to experimental ecosystem warming. Oecologia 126:543-562.

SHIPLEY, B., PAINE, C. E. T. \& BARALOTO, C. 2012. Quantifying the importance of local niche-based and stochastic processes to tropical tree community assembly. Ecology 93:760-9.

TANNER, E. V. J. 1998a. Experimental Investigation of Nutrient Limitation of Forest Growth on Wet Tropical Mountains. Ecology 79:10-22.

TANNER, E. V. J. 1998b. Studies on the Biomass and Productivity in a Series of Montane Rain Forests in Jamaica. Journal of Ecology 68:573-588.

TERBORGH, J. 1977. Bird species diversity on an Andean elevational gradient. Ecology 58:1007-1019.

VITOUSEK, P. M. \& HOWARTH, R. W. 2008. Nitrogen limitation on land and in the sea: How can it occur? 13:87-115.

VOGT, K. A., VOGT, D. J., PALMIOTTO, P. A., BOON, P., O'HARA, J. \& ASBJORNSEN, H. 1995. Review of root dynamics in forest ecosystems grouped by climate, climatic forest type and species. Plant and Soil 187:159-219.

WAIDE, R. B., ZIMMERMAN, J. K. \& SCATENA, F. N. 1998. Controls of primary productivity: lessons from the Luquillo Mountains in Puerto Rico. Ecology 79:3137.

VAN DE WEG, M. J., MEIR, P., GRACE, J. \& ATKIN, O. K. 2009. Altitudinal variation in leaf mass per unit area, leaf tissue density and foliar nitrogen and phosphorus content along an Amazon-Andes gradient in Peru. Plant Ecology \& Diversity 2:243-254.

WEST, G. B., BROWN, J. H. \& ENQUIST, B. J. 1999. A general model for the structure and allometry of plant vascular systems 400:664-667.

WRIGHT, I. J., REICH, P. B., WESTOBY, M., ACKERLY, D. D., BARUCH, Z., BONGERS, F., CAVENDER-BARES, J., CHAPIN, T., CORNELISSEN, J. H. C., DIEMER, M., FLEXAS, J., GARNIER, E., GROOM, P. K., GULIAS, J., HIKOSAKA, K., LAMONT, B. B., LEE, T., LEE, W., LUSK, C., MIDGLEY, J. J., NAVAS, M.-L., NIINEMETS, U., OLEKSYN, J., OSADA, N., POORTER, H., POOT, P., PRIOR, L., PYANKOV, V. I., ROUMET, C., THOMAS, S. C., 
TJOELKER, M. G., VENEKLAAS, E. J. \& VILLAR, R. 2004a. The worldwide leaf economics spectrum. Nature 428:821-827.

WRIGHT, I. J. \& WESTOBY, M. 1999. Differences in seedling growth behaviour among species: trait correlations across species, and trait shifts along nutrient compared to rainfall gradients. Journal of Ecology 87:85-97.

WRIGHT, S. J., BUNKER, D., DALLING, J., DAVIES, S., DÍAZ, S., HARMS, K., KITAJIMA, K., KRAFT, N., MARKS, C., ENGELBRECHT, B., REICH, P., VALENCIA, R., WRIGHT, I. \& WRIGHT, J. 2004b. Towards a functional trait based research program within the Center for Tropical Forest Science. Pp. 1-15.

XIE, J., TANG, L., WANG, Z., XU, G. \& LI, Y. 2012. Distinguishing the biomass allocation variance resulting from ontogenetic drift or acclimation to soil texture. PloS one 7:e41502.

YOUNG, K. R. \& LEÓN, B. 1999. Peru's humid eastern montane forests: An overview of their physical settings, biological diversity, human use and settlement, and conservation needs. Centre for Research on the Cultural and Biological Diversity of Andean Rainforests (DIVA).

ZIMMERMANN, M., MEIR, P., SILMAN, M. R., FEDDERS, A., GIBBON, A., MALHI, Y., URREGO, D. H., BUSH, M. B., FEELEY, K. J., GARCIA, K. C., DARGIE, G. C., FARFAN, W. R., GOETZ, B. P., JOHNSON, W. T., KLINE, K. M., MODI, A. T., RURAU, N. M. Q., STAUDT, B. T. \& ZAMORA, F. 2009. No Differences in Soil Carbon Stocks Across the Tree Line in the Peruvian Andes. Ecosystems 13:62-74. 


\section{$\underline{\text { Tables }}$}

Table 1. Information extracted from the ABERG plot database showing the importance of the species selected

\begin{tabular}{|c|c|c|c|c|c|}
\hline $\begin{array}{l}\text { Elevation } \\
\text { (m asl) }\end{array}$ & $\begin{array}{c}\text { Range of } \\
\text { Aboveground } \\
\text { biomass (kg) }\end{array}$ & Species & $\begin{array}{c}\text { Average } \\
\text { DBH }(\mathrm{cm})\end{array}$ & $\begin{array}{c}\text { Average } \\
\text { Height (m) }\end{array}$ & $\begin{array}{c}\text { Average } \\
\text { Aboveground } \\
\text { biomass }(\mathrm{kg})^{*}\end{array}$ \\
\hline \multirow{6}{*}{2750} & \multirow{6}{*}{$\begin{array}{l}16.75- \\
474.31\end{array}$} & Clusia alata & 21.47 & 13.71 & 196.56 \\
\hline & & Clusia flaviflora & - & - & - \\
\hline & & Symplocos psiloclada & 10.10 & 10.00 & 32.32 \\
\hline & & Symplocos quitensis & - & - & - \\
\hline & & Weinmania bangii & 24.77 & 13.87 & 310.64 \\
\hline & & Weinmania microphylla & - & - & - \\
\hline \multirow{6}{*}{3000} & \multirow{6}{*}{$\begin{array}{l}14.42- \\
463.18\end{array}$} & Clusia alata & 20.22 & 11.41 & 153.99 \\
\hline & & Clusia flaviflora & 28.46 & 12.66 & 357.37 \\
\hline & & Symplocos psiloclada & 18.20 & 10.00 & 123.44 \\
\hline & & Symplocos quitensis & - & - & - \\
\hline & & Weinmania bangii & 17.74 & 11.45 & 128.91 \\
\hline & & Weinmania microphylla & - & - & - \\
\hline \multirow{6}{*}{3250} & \multirow{6}{*}{$\begin{array}{c}16.87- \\
1078.17\end{array}$} & Clusia alata & 22.89 & 10.61 & 169.79 \\
\hline & & Clusia flaviflora & 14.10 & 6.00 & 37.44 \\
\hline & & Symplocos psiloclada & 19.78 & 9.80 & 137.30 \\
\hline & & Symplocos quitensis & 28.43 & 11.29 & 469.98 \\
\hline & & Weinmania bangii & 22.55 & 12.34 & 283.55 \\
\hline & & Weinmania microphylla & 25.79 & 11.83 & 322.57 \\
\hline \multirow{6}{*}{3450} & \multirow{6}{*}{$\begin{array}{l}10.23- \\
764.84\end{array}$} & Clusia alata & 20.40 & 9.67 & 129.01 \\
\hline & & Clusia flaviflora & 26.41 & 8.14 & 197.30 \\
\hline & & Symplocos psiloclada & 18.08 & 6.44 & 79.32 \\
\hline & & Symplocos quitensis & 23.91 & 9.80 & 217.53 \\
\hline & & Weinmania bangii & - & - & - \\
\hline & & Weinmania microphylla & 29.92 & 10.05 & 322.09 \\
\hline
\end{tabular}


Table 2.Correlations among the environmental variables of the study

\begin{tabular}{|l|c|c|c|}
\hline Pearson's r & $\mathrm{pH}$ & light & elevation \\
\hline $\mathrm{pH}$ & & 0.23 & -0.03 \\
\hline light & & & 0.11 \\
\hline elevation & & & \\
\hline
\end{tabular}




\section{Figures}

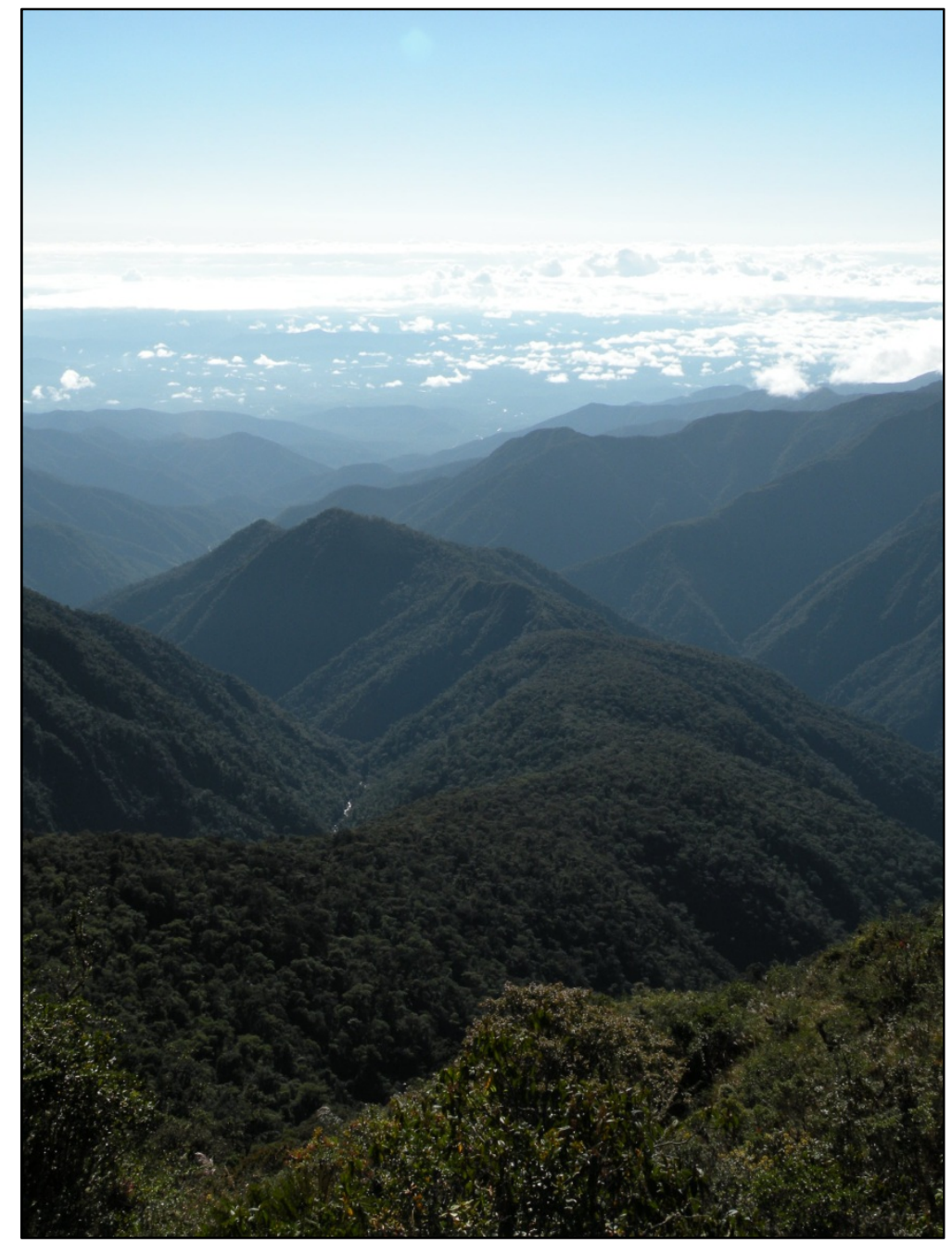

Figure 1. View of the field study from $3500 \mathrm{~m}$ asl, top of the ridge called Trocha Union, to the east over the study site in the Kosnipata Valley, Cusco - Peru. Seedlings were collected along the shown ridge from $3450 \mathrm{~m}$ to $2700 \mathrm{~m}$. 


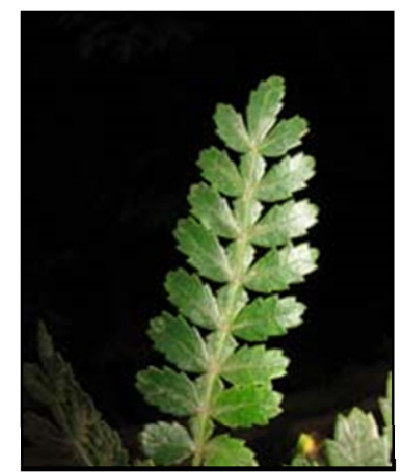

Weinmannia microphylla

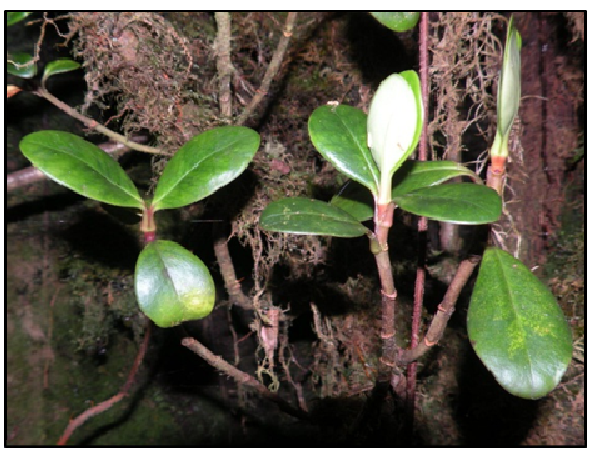

Clusia alata

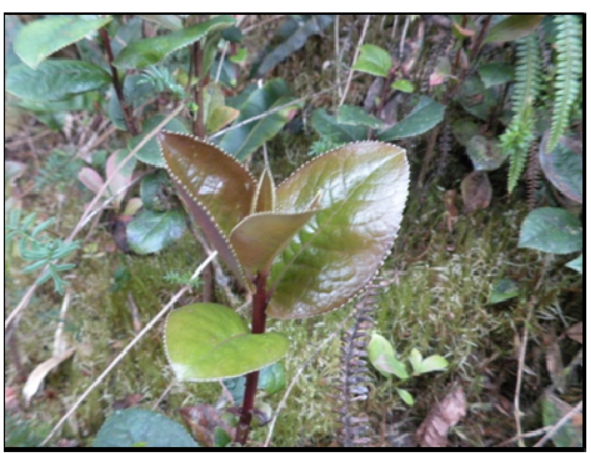

Symplocos quitensis

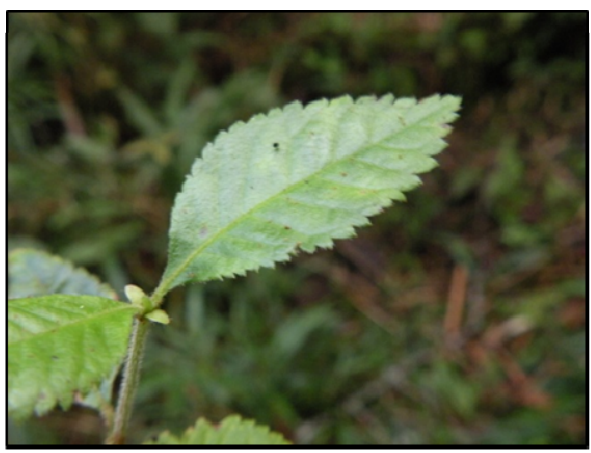

Weinmannia bangii

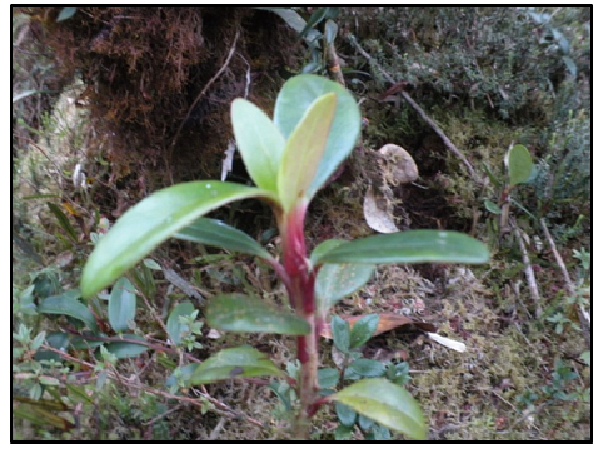

Clusia flaviflora

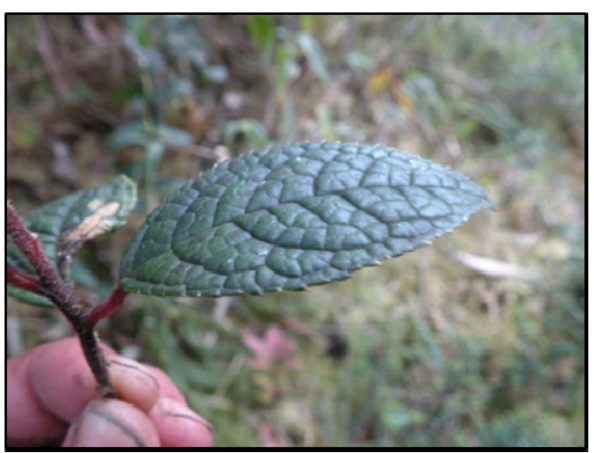

Symplocos psiloclada

Figure 2. Seedlings of the six focal species taken in the field. 

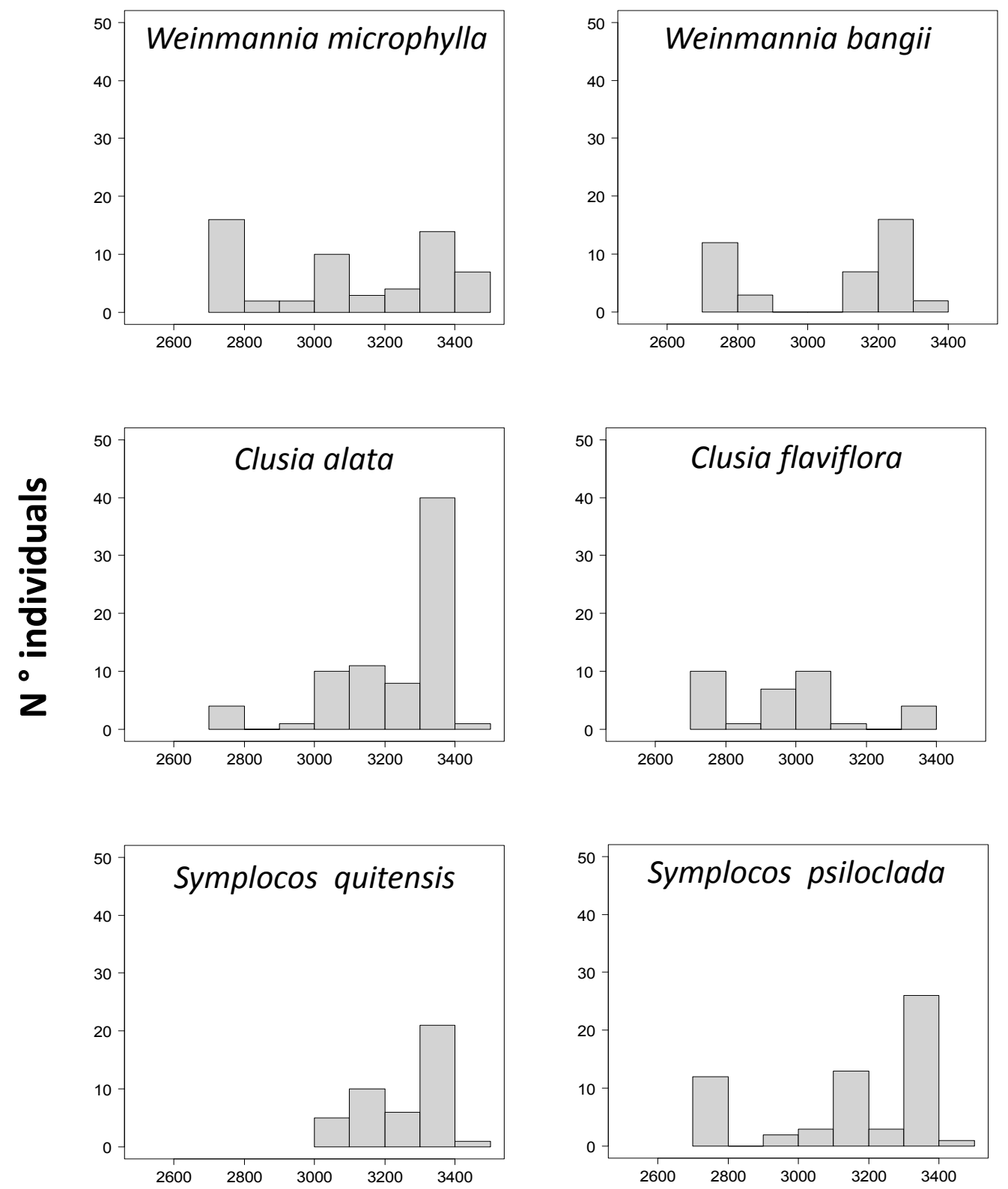

\section{Elevation (masl)}

Figure 3. Histograms that show the number of seedlings collected by species per elevation. 


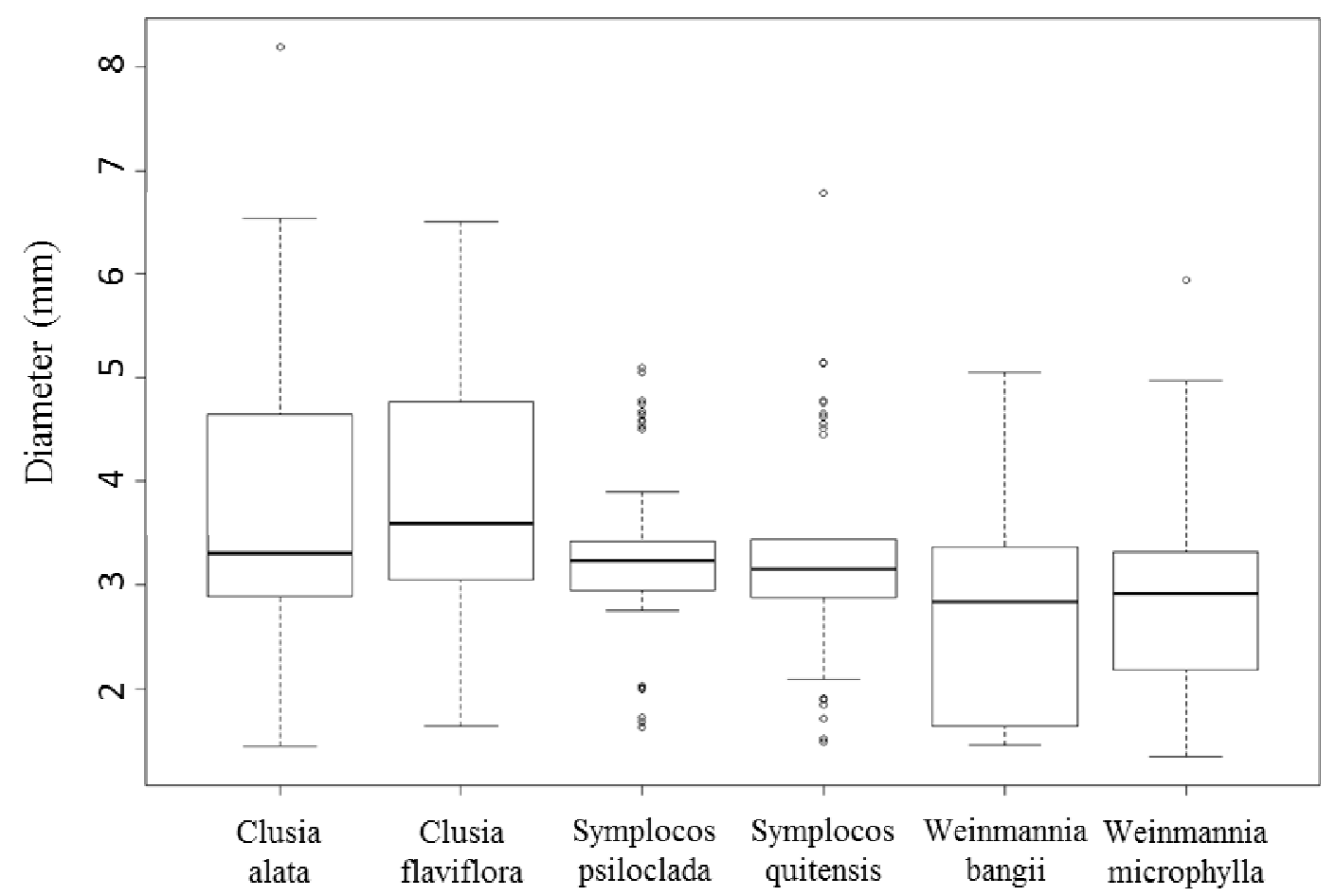

Figure 4. Mean basal diameter $(\mathrm{mm})$ presented by species across the elevational gradient. 


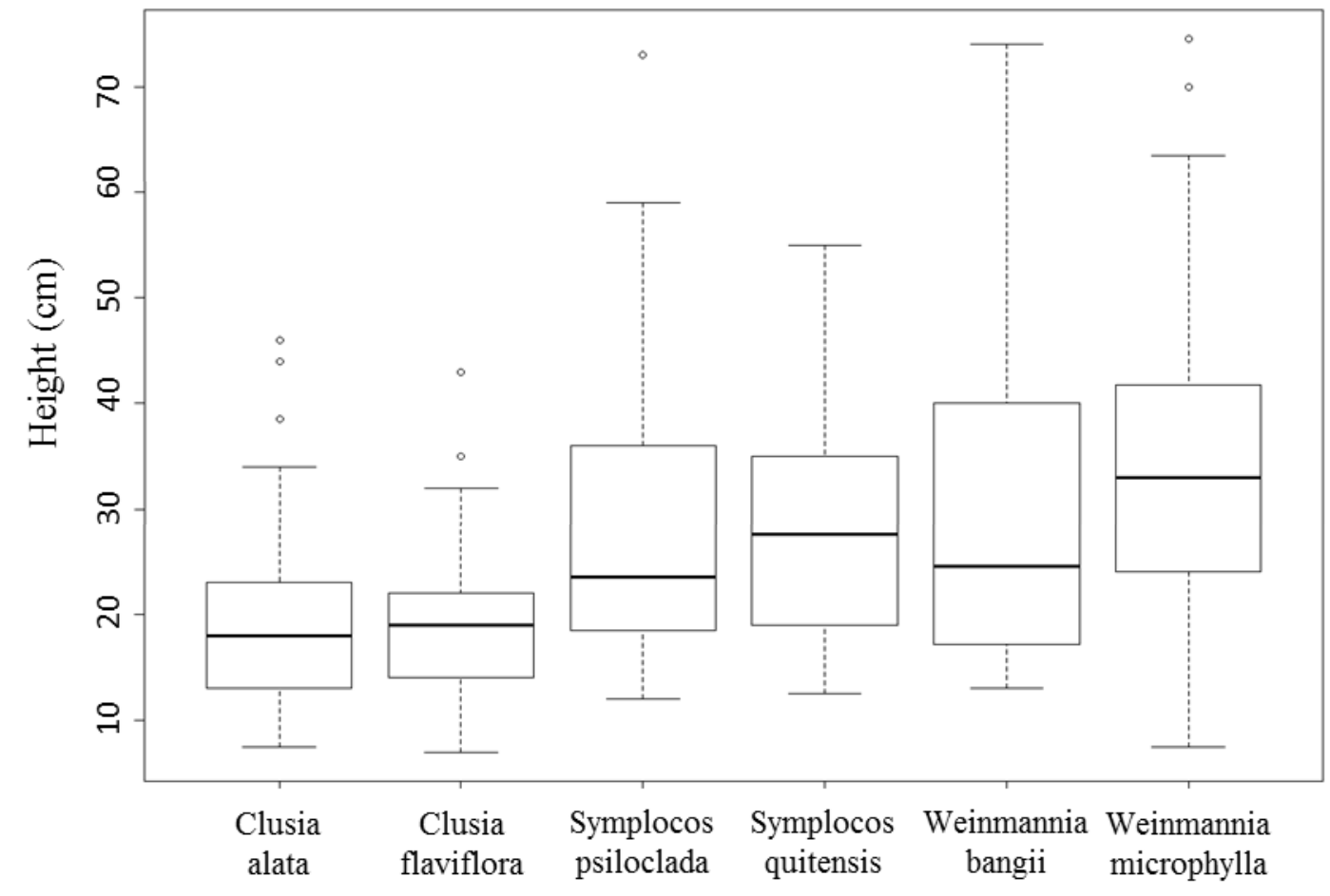

Figure 5. Mean shoot height $(\mathrm{cm})$ presented by species across the elevational gradient. 

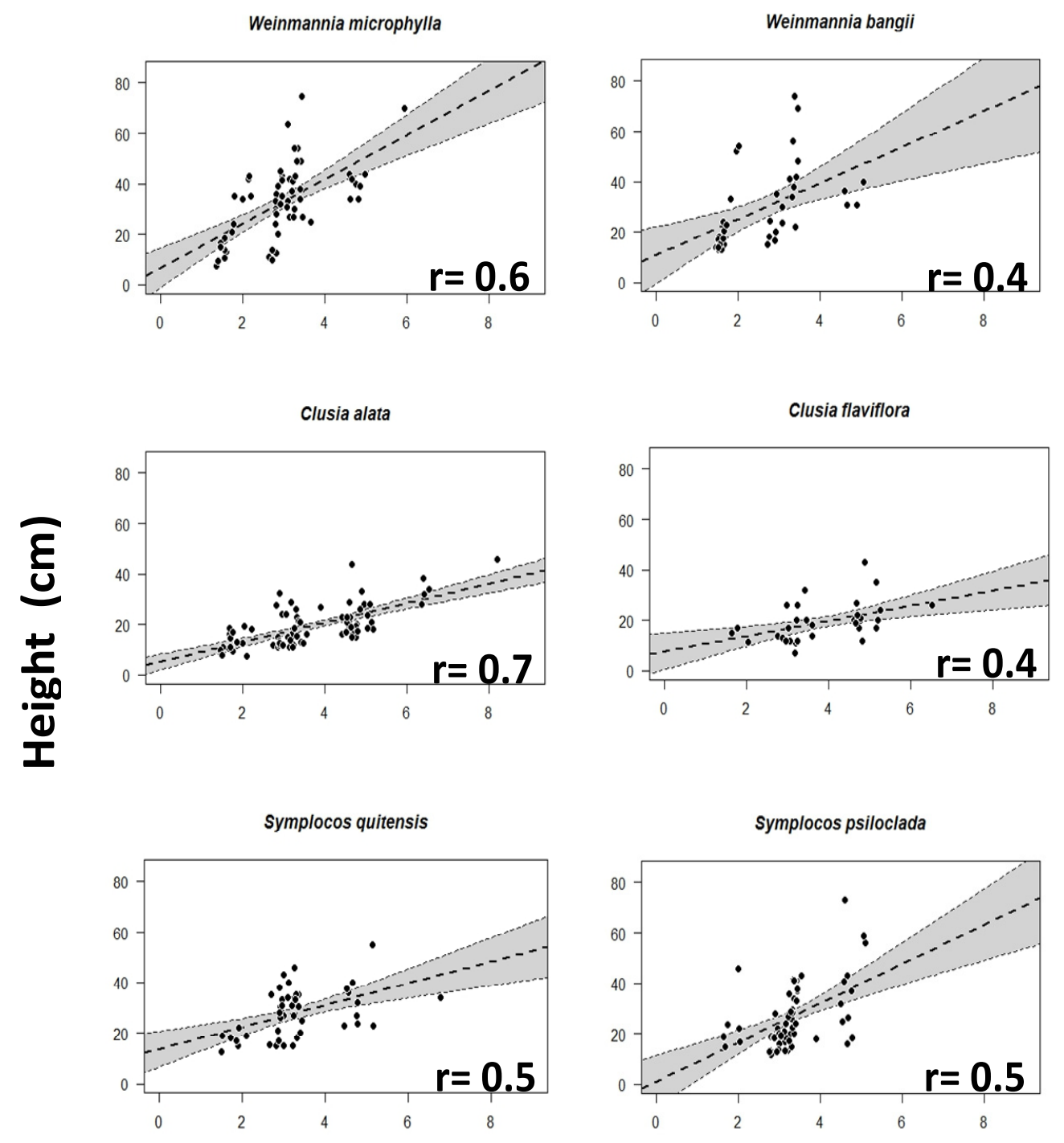

\section{Diameter $(\mathrm{mm})$}

Figure 6. Regression line between plant height $(\mathrm{cm})$ and basal diameter $(\mathrm{mm})$, including the $90 \%$ confidence interval (gray color), presented by species. Pearson correlation coefficients (r) are reported. 

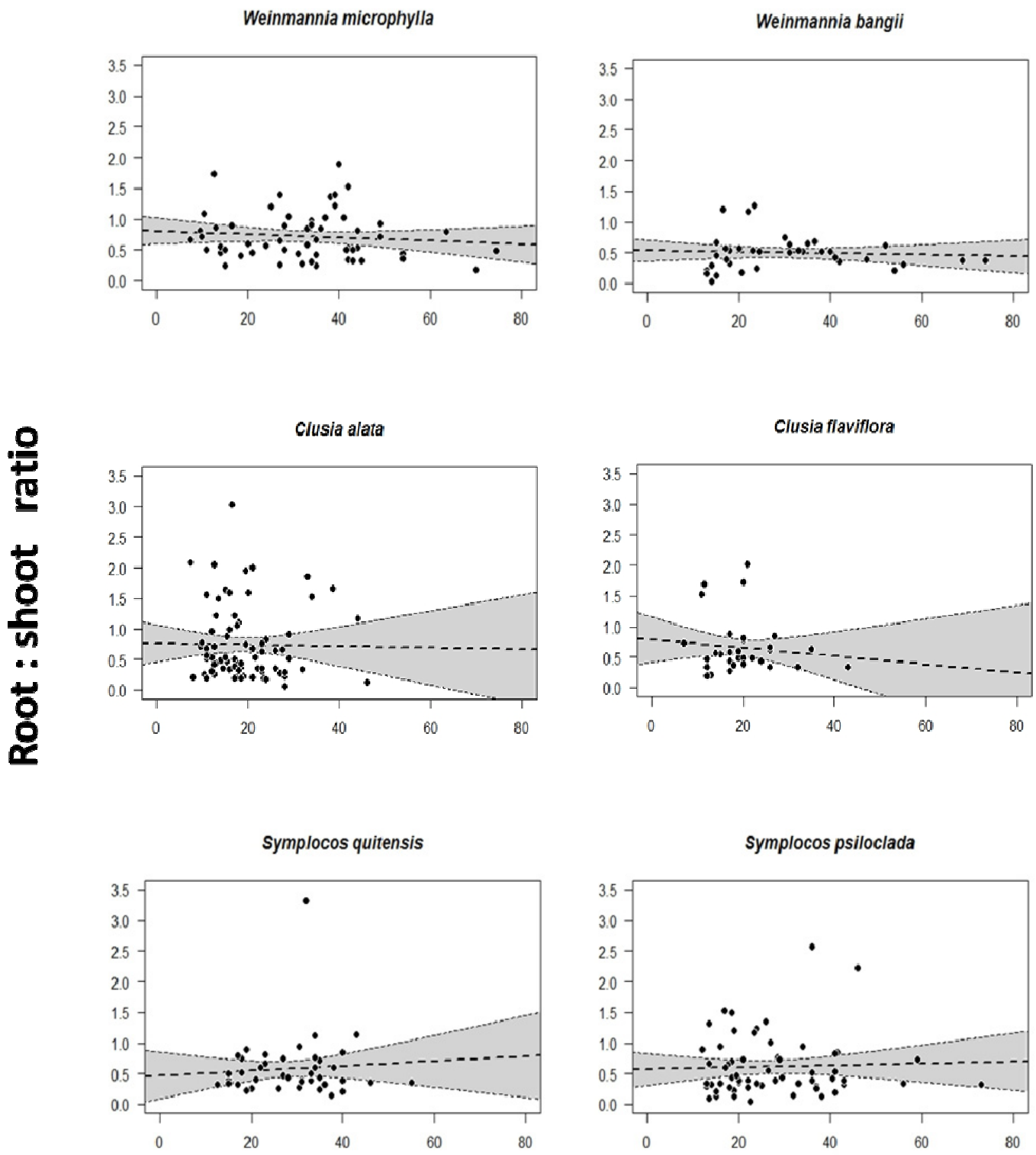

\section{Height (cm)}

Figure 7. Regression line between root:shoot ratio and height $(\mathrm{cm})$, including the $90 \%$ confidence interval (gray color), presented by species. 
Weinmannia microphylla

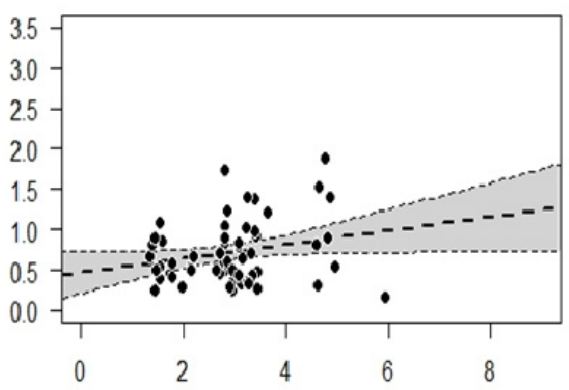

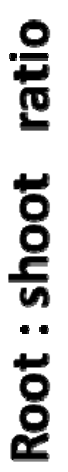

Symplocos quitensis

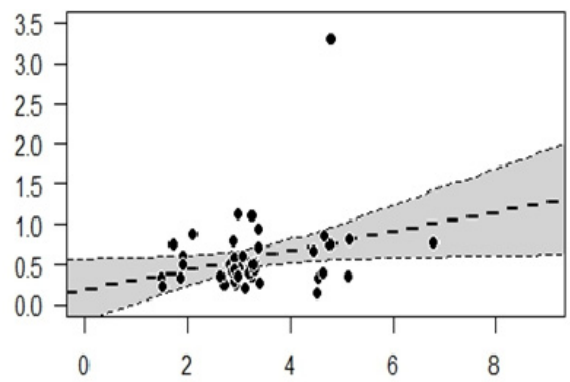

Weinmannia bangii

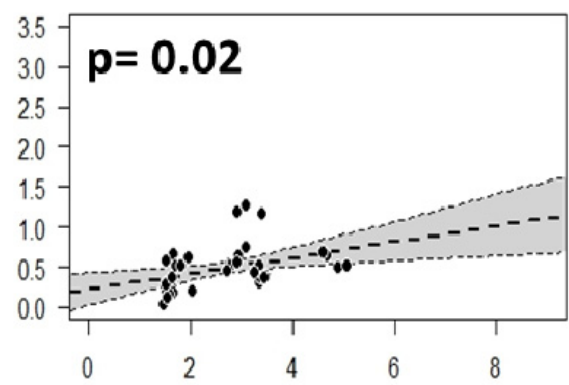

Clusia flaviflora

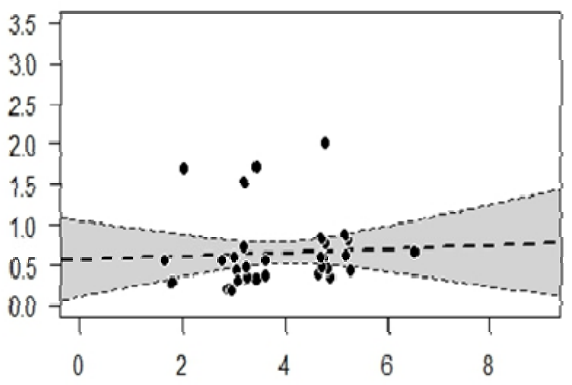

symplocos psiloclada

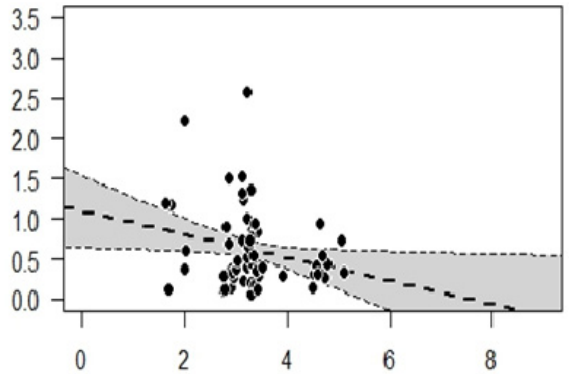

\section{diameter ( $\mathrm{mm})$}

Figure 8. Regression line between root:shoot ratio and basal diameter ( $\mathrm{mm}$ ), including the $90 \%$ confidence interval (gray color), presented by species. 

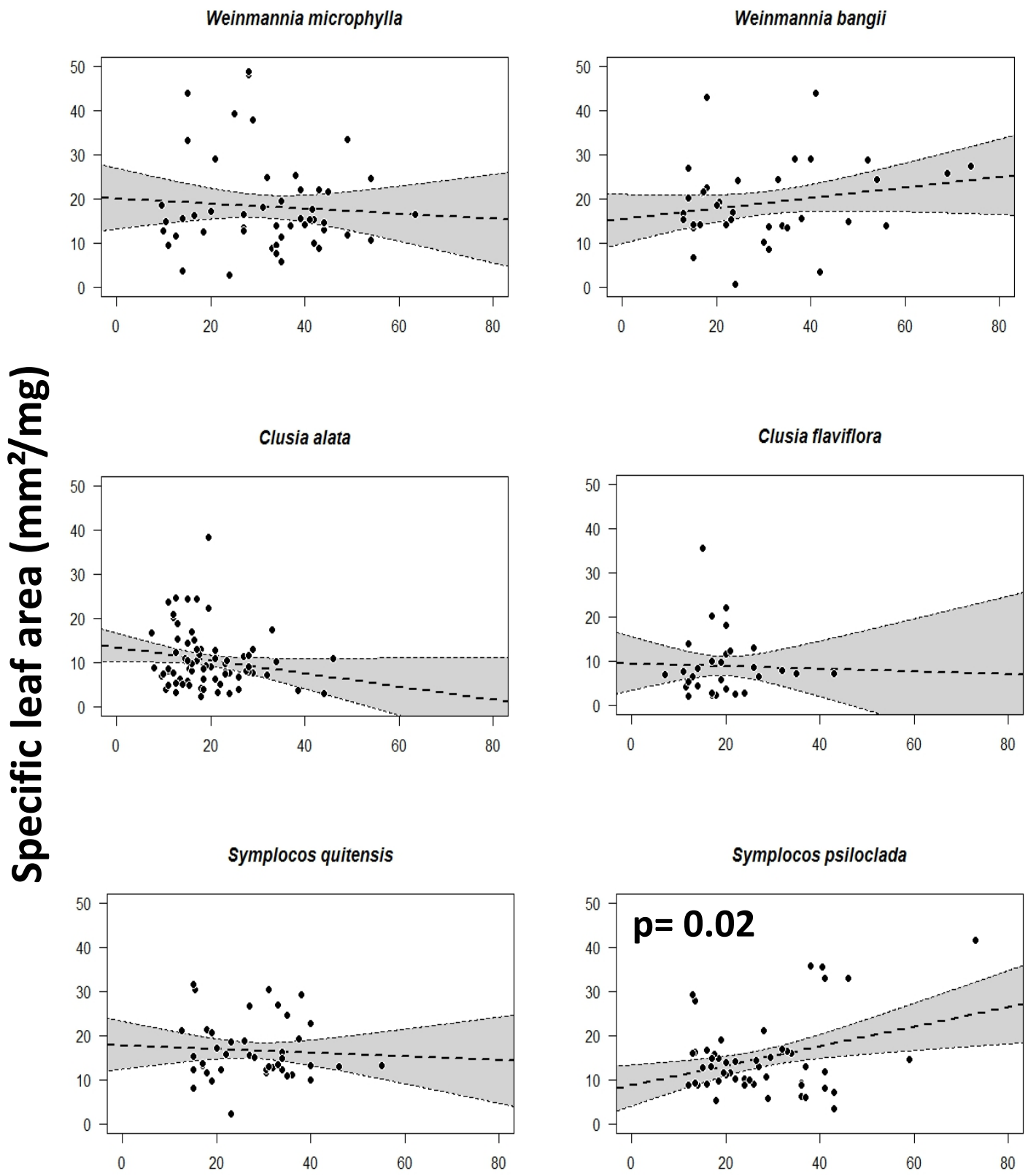

\section{Height (cm)}

Figure 9. Regression line between specific leaf area $\left(\mathrm{mm}^{2} / \mathrm{mg}\right)$ and height $(\mathrm{cm})$, including the $90 \%$ confidence interval (gray color), presented by species. 

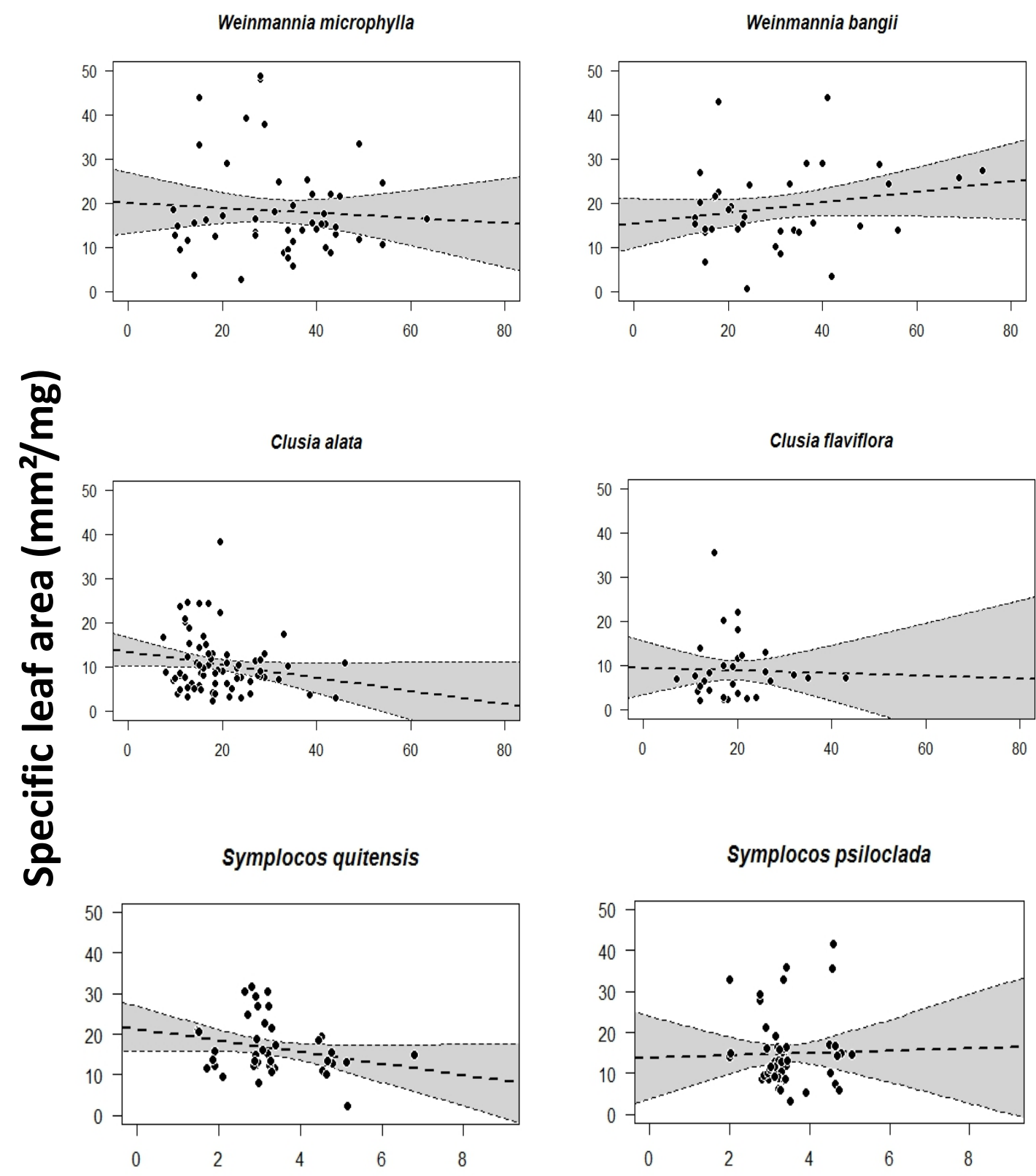

\section{Diameter $(\mathrm{mm})$}

Figure 10. Regression line between specific leaf area $\left(\mathrm{mm}^{2} / \mathrm{mg}\right)$ and diameter $(\mathrm{mm})$, including the $90 \%$ confidence interval (gray color), presented by species. 


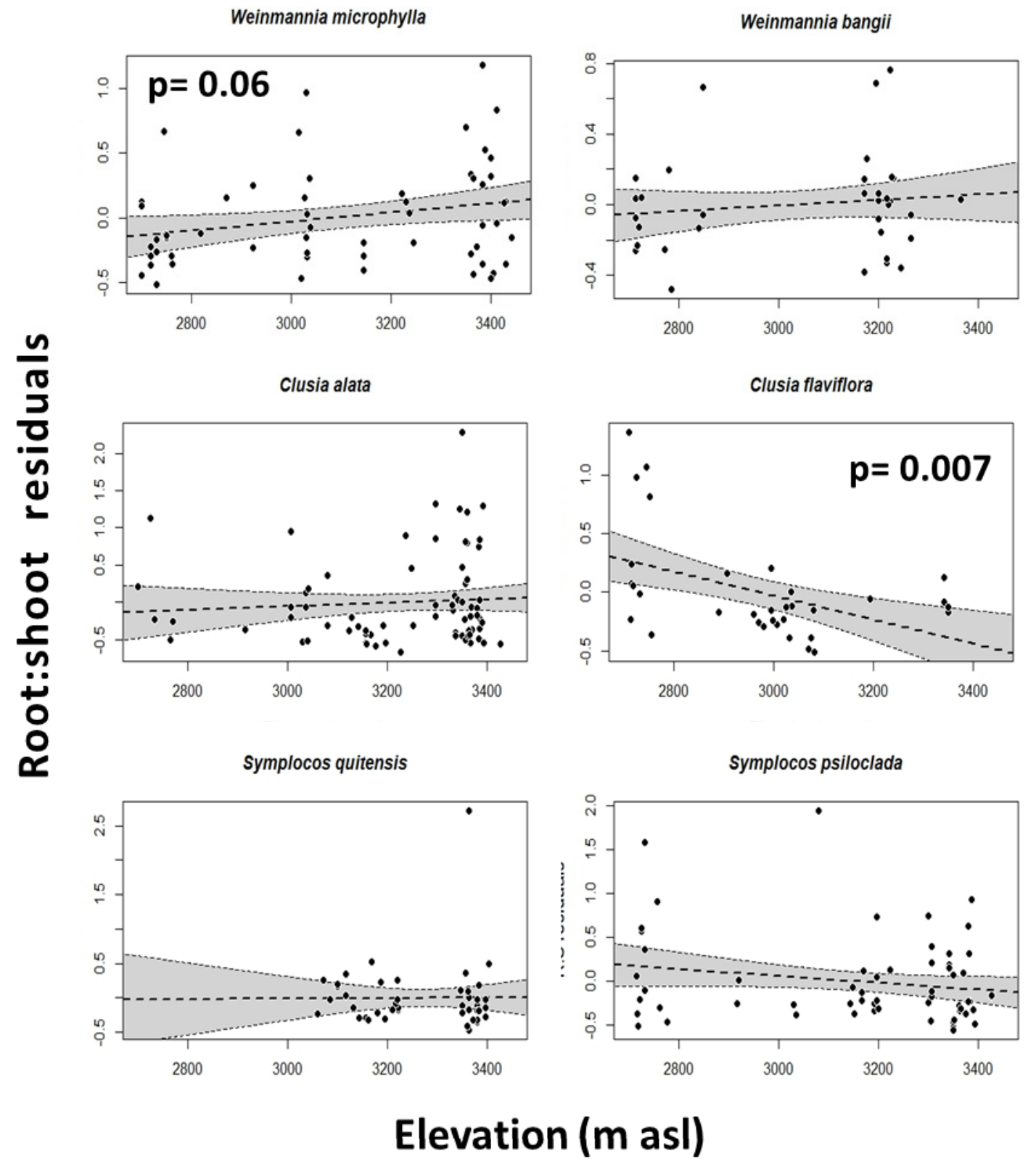

Figure 11. Regression line between root:shoot ratio residuals and elevation ( $\mathrm{m}$ asl), including the $90 \%$ confidence interval (gray color), presented by species. 


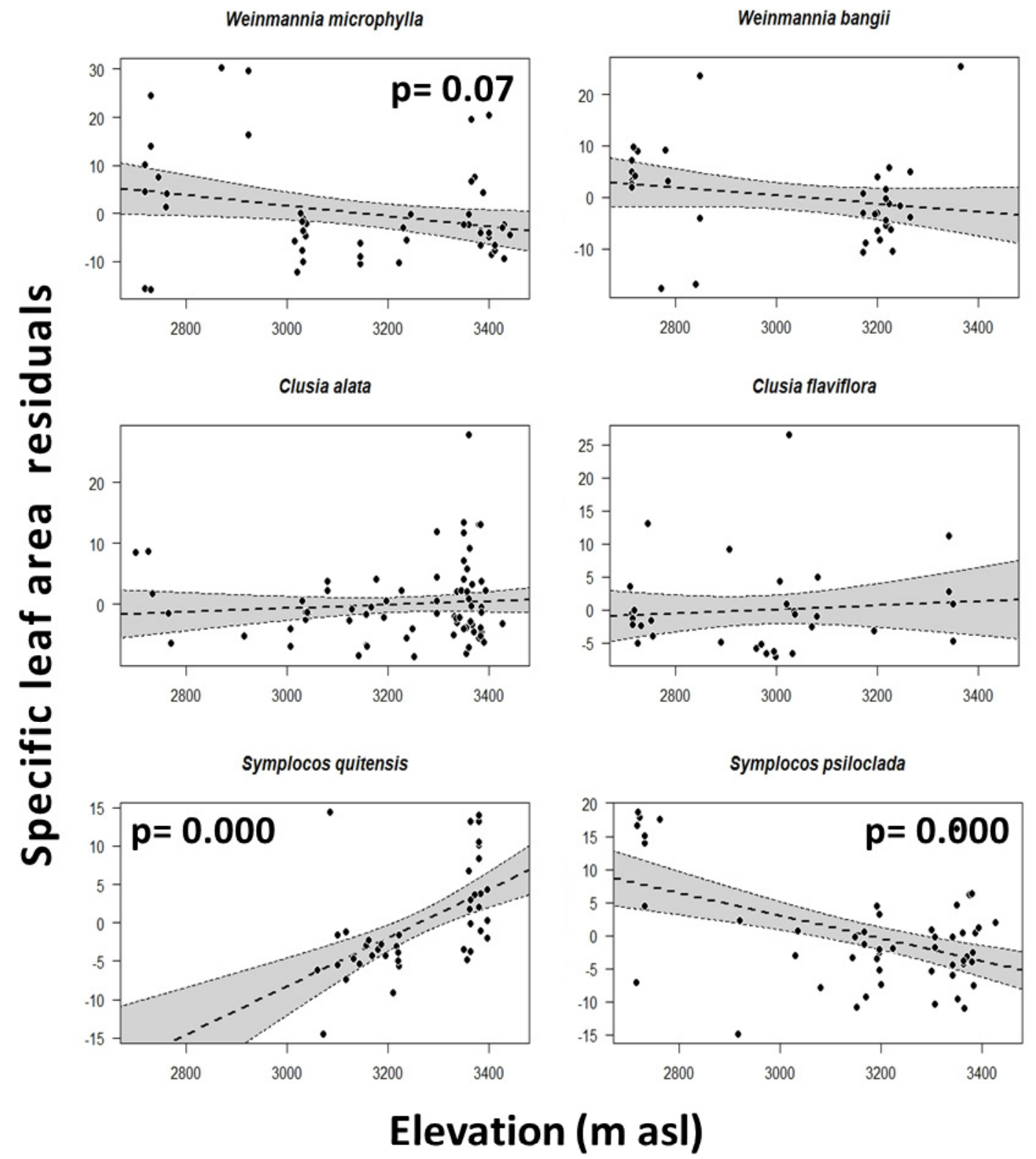

Figure 12. Regression line between specific leaf area residuals and elevation ( $\mathrm{m}$ asl), including the $90 \%$ confidence interval (gray color), presented by species. 


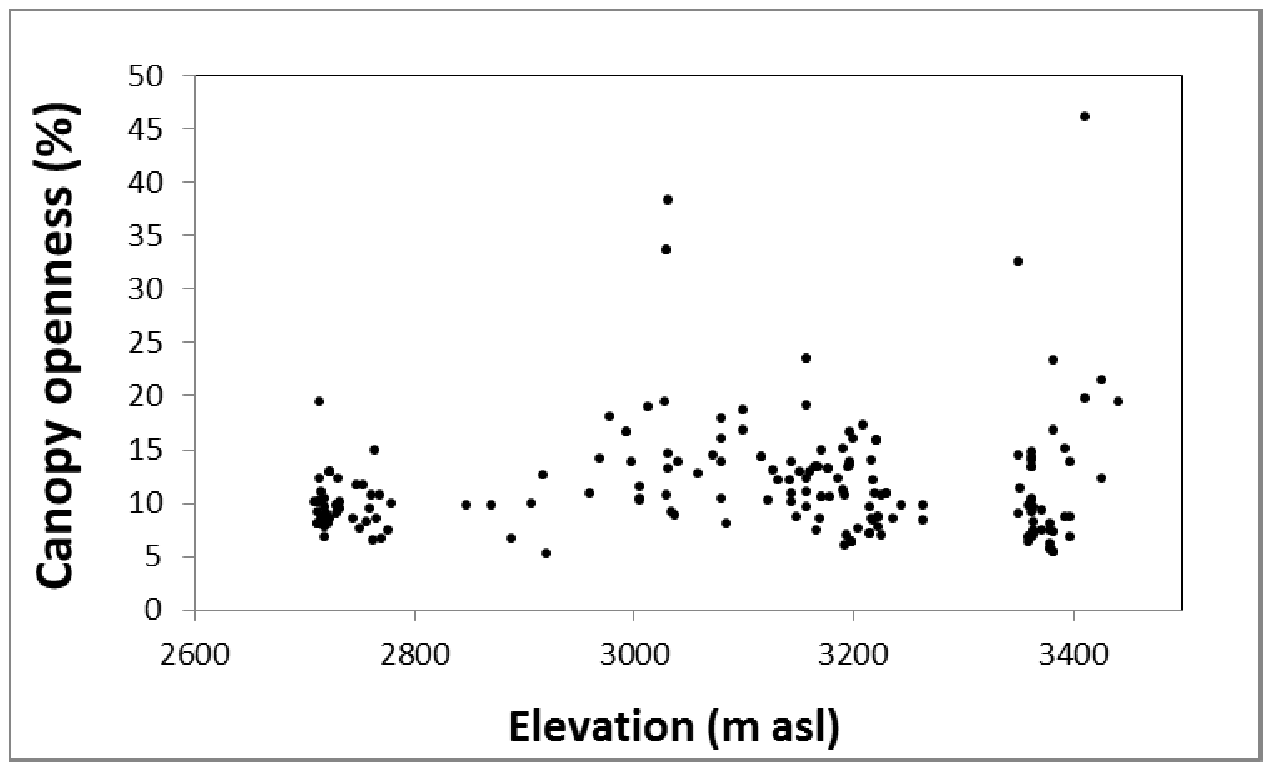

Figure 13. Canopy openness (\%) taken from each location where seedlings were collected $(n=190$ pictures) 

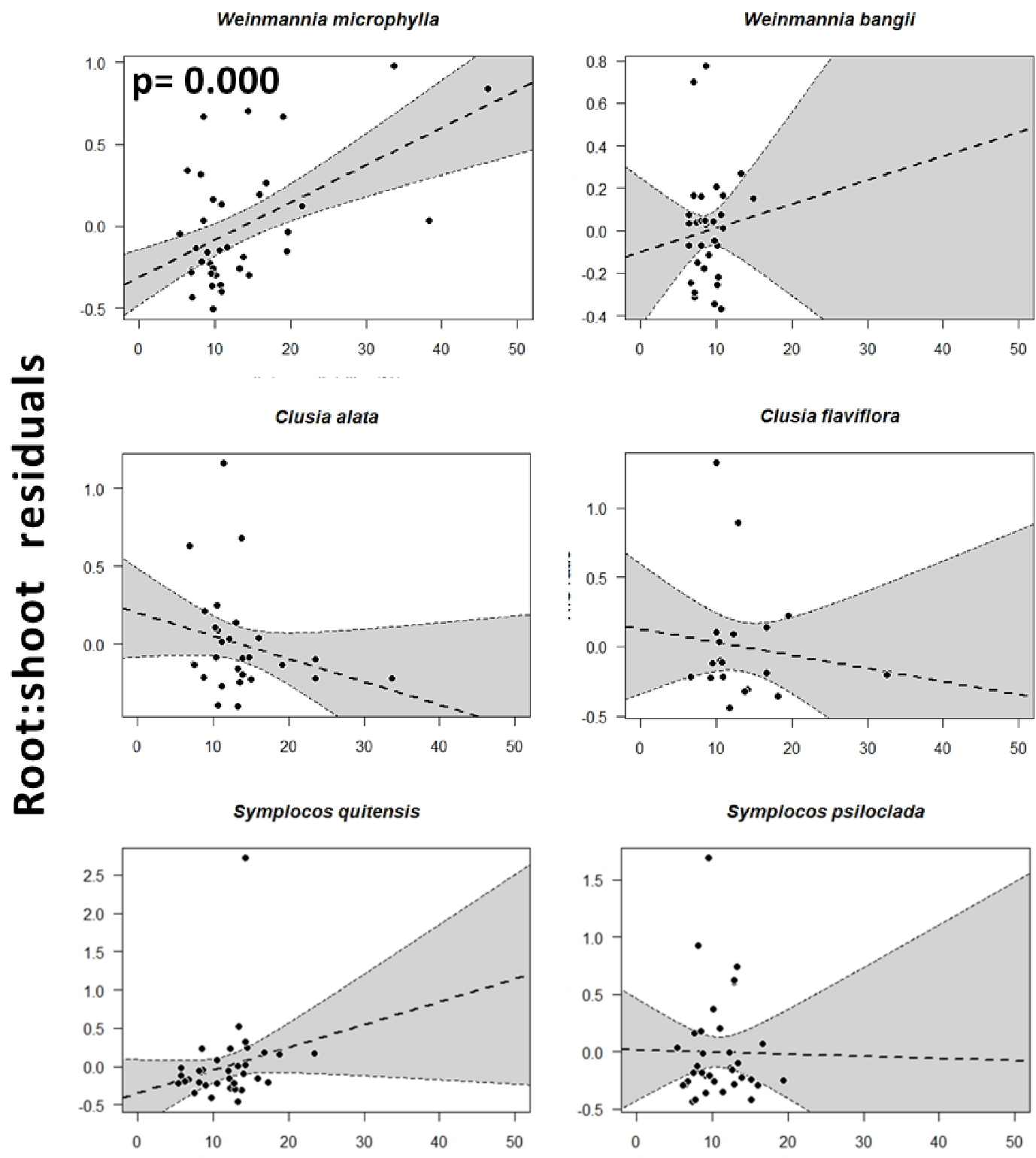

\section{Canopy openness (\%)}

Figure 14. Regression line between root:shoot ratio residuals and canopy openness (\%), including the $90 \%$ confidence interval (gray color), presented by species. 

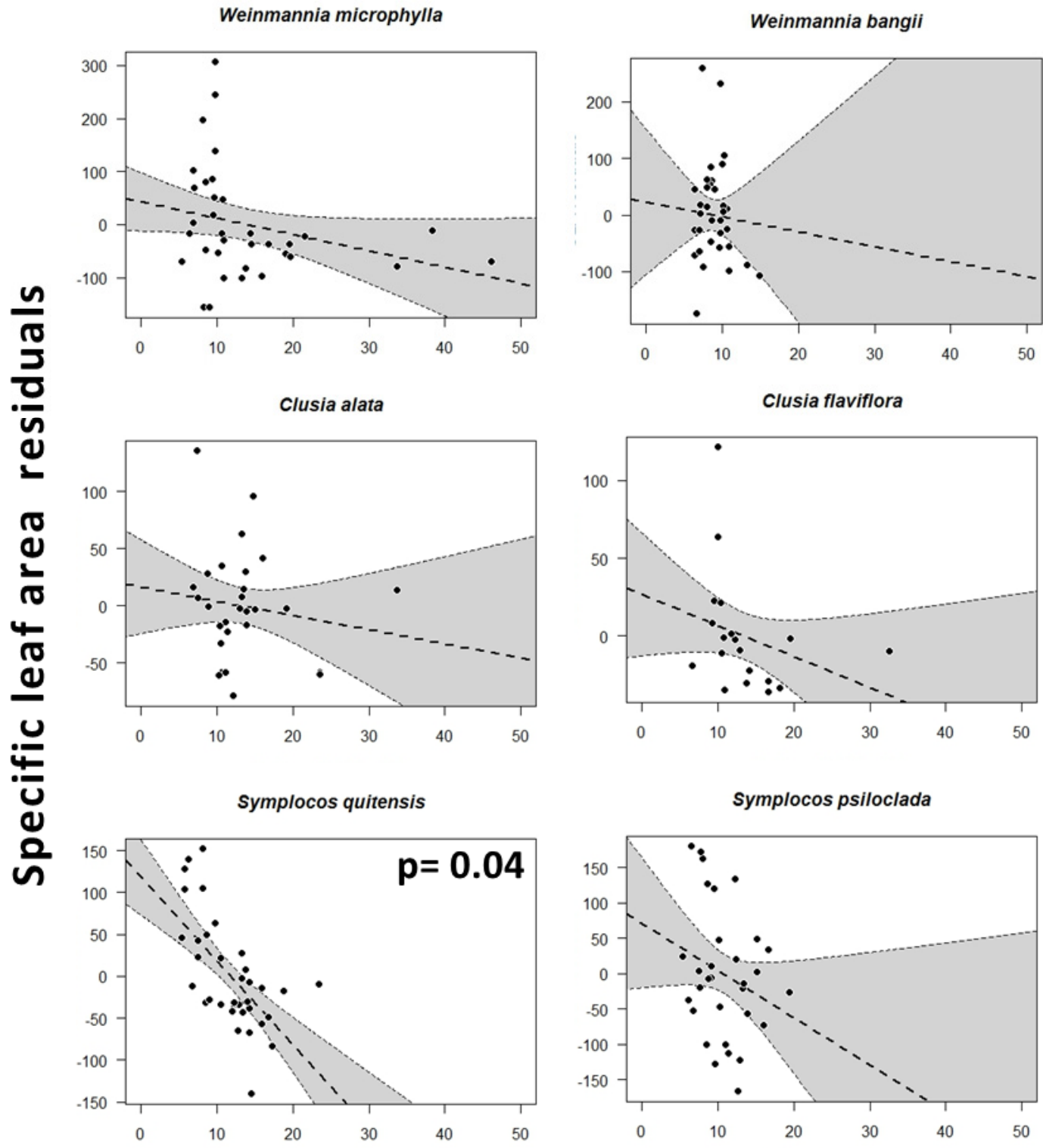

Canopy openness (\%)

Figure 15. Regression line between specific leaf area residuals and canopy openness (\%), including the $90 \%$ confidence interval (gray color), presented by species. 


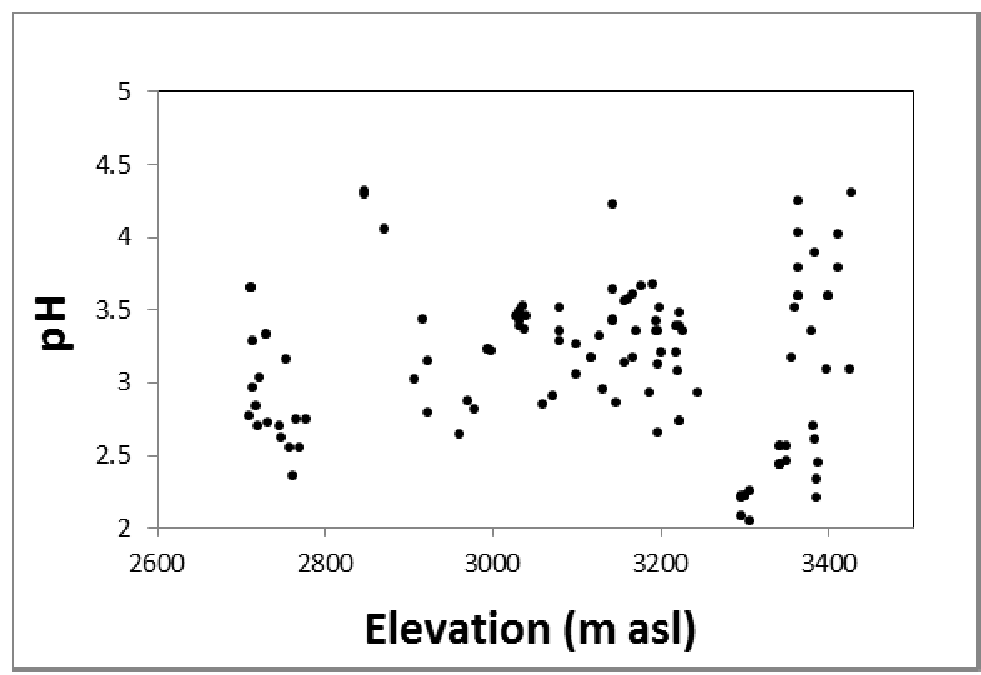

Figure 16. Regression line that shows the distribution of soil $\mathrm{pH}$ along the elevational gradient.(n=119) 

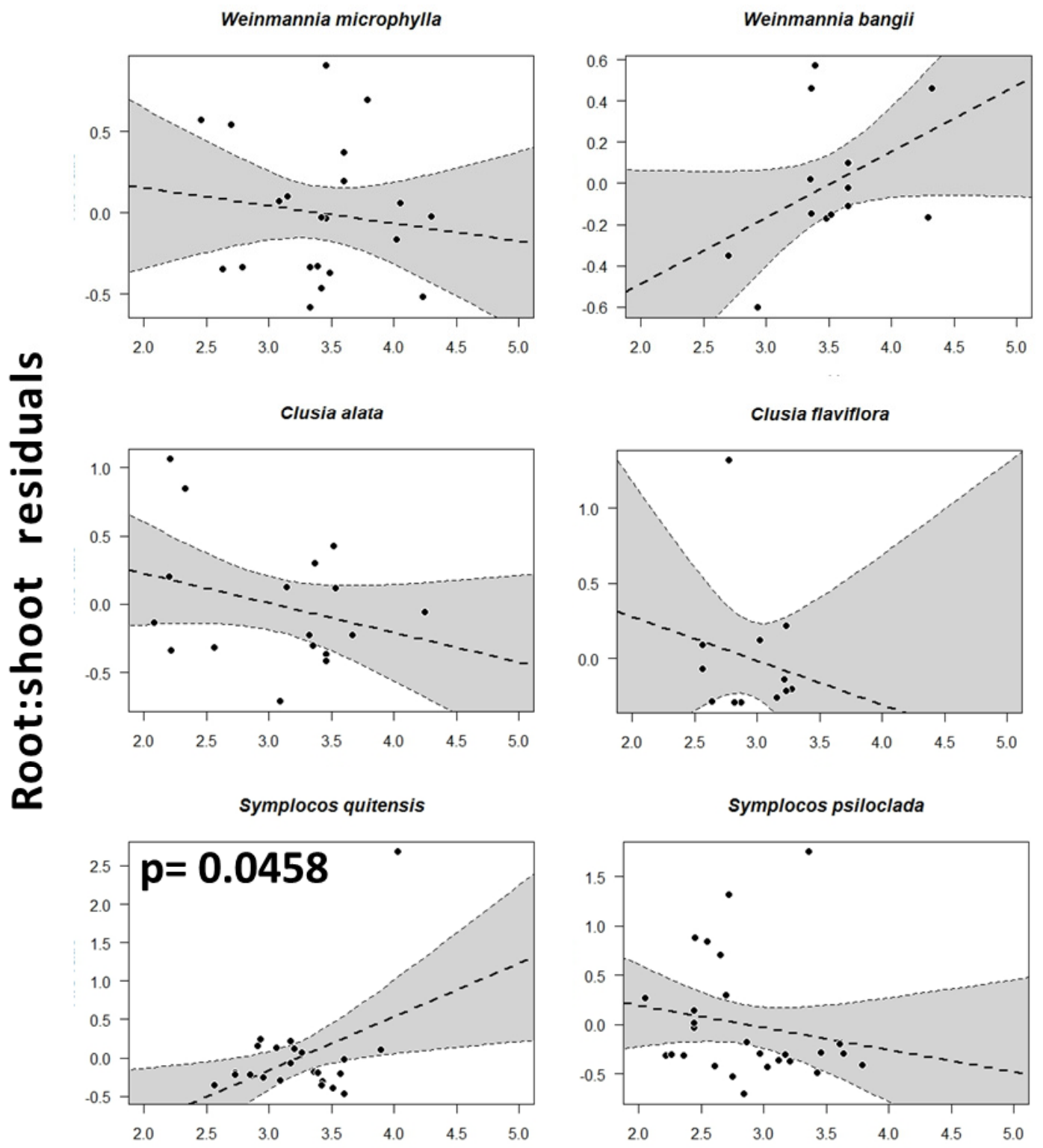

\section{pH}

Figure 17. Regression line between root:shoot ratio residuals and $\mathrm{pH}$, including the $90 \%$ confidence interval (gray color), presented by species. 


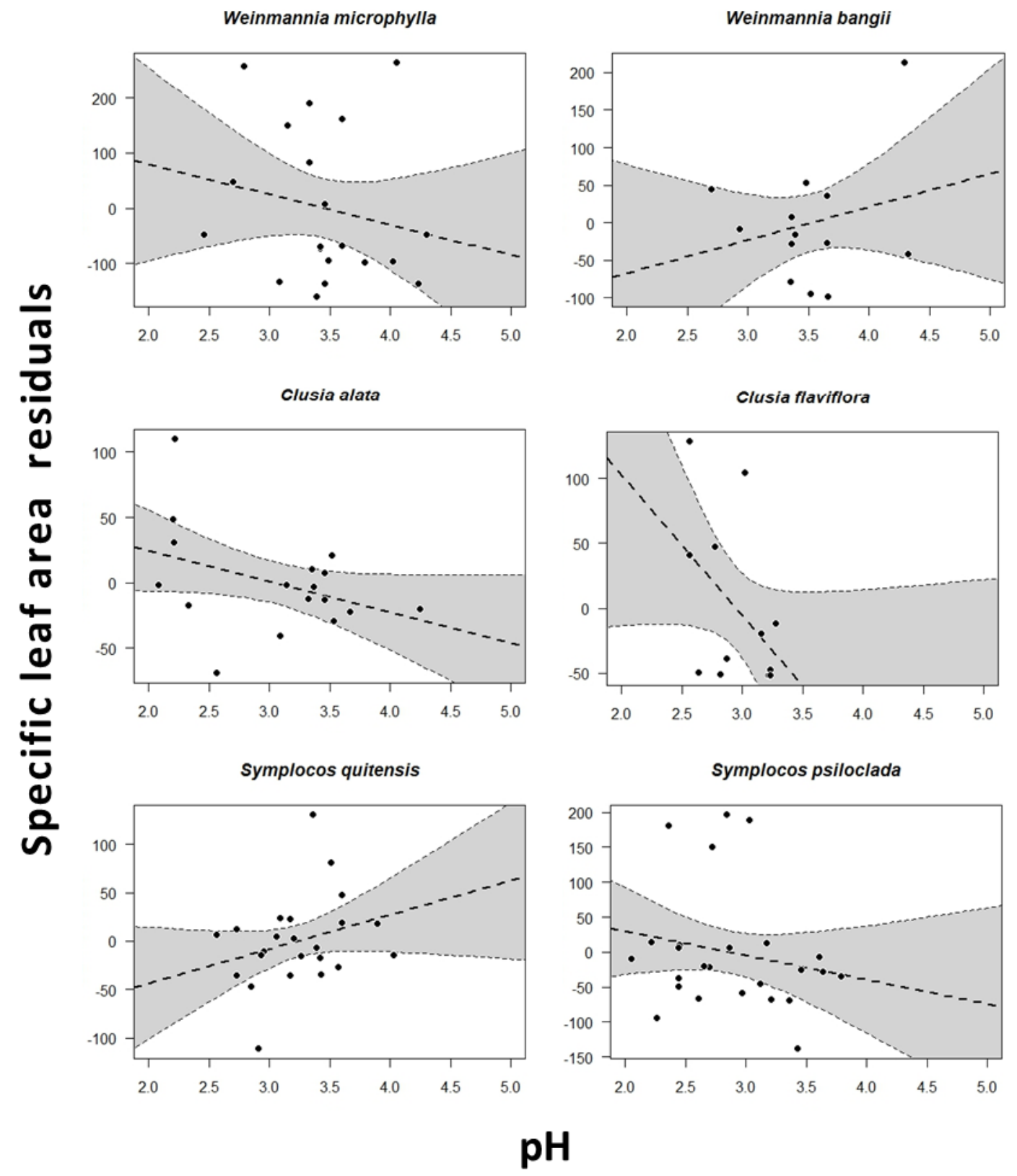

Figure 18. Regression line between specific leaf area residuals and $\mathrm{pH}$, including the $90 \%$ confidence interval (gray color), presented by species. 